\title{
Civic honours and political participation in late antique Italy*
}

Carlos Machado

At some point in the middle of the fourth century, the inhabitants of Trebula Balliensis, in Campania, dedicated a statue to the local notable Lucius Alfius Fannius Primus So[---]. ${ }^{1}$ Alfius was a patron of the city at the time of the dedication; he had a successful career in local politics, having served as quaestor, supervisor of the grain supply, and duumvir. According to the inscription, he was honoured for restoring the city's thermae Constantinianae. As the dedication records, "the senate and people of Trebula (...) voted the statue, with a decree of the decurions." The monument to Alfius is important evidence for our picture of urban life in late antique Italy: it attests to the survival of traditional magistracies and of centuries-old forms of benefaction in the fourth century; the dedication of the statue illustrates the continued importance of traditional forms of civic honours in the relationship between cities and their elites; and perhaps more importantly, the reference to the vote of the senate and people highlights the vitality of civic life at a time of dramatic historical changes. Alfius' monument was also a relic of a practice that had, by that time, mostly disappeared: one of the last such civic honours bestowed by the Trebulani in Antiquity. ${ }^{2}$

Civic honours were a crucial component in ancient city life. They allowed local political groups and associations to express social and political hierarchies, to reward benefactors, and to celebrate traditional values and identities - an essential "lubricant" in the political, social, and cultural life of Greco-Roman cities. ${ }^{3}$ As the

\footnotetext{
* I have followed the Guide de l'épigraphiste (2010) for abbreviations of epigraphic publications. For the sake of convenience, I refer to inscriptions by their main print and (when possible) online publication in EDR (Epigraphic Database Roma: http://www.edr-edr.it/default/index.php) or LSA (Last Statues of Antiquity: http://laststatues.classics.ox.ac.uk). I would like to thank all colleagues involved in the $L S A$ project, especially its directors R. R. R. Smith and Bryan Ward-Perkins, as well as Paolo Liverani, Silvia Orlandi, Ignazio Tantillo, and Christian Witschel, for their support. I am particularly grateful to Jill Harries, for her invaluable generosity with comments and suggestions.

${ }^{1}$ CIL X, 4559=LSA-1962: L(ucio) Alfio Fannio Primo So[---] / quaest(ori), curatori frumento, / $\mathrm{du}(\mathrm{u})$ mviro, omnib(us) honerib(us) et / honoribus functo, sacerd(otali) / viro, patrono et curatori / [---] A PISONI aurum atque / argentum obraetium se/rio ilustravit, thermas ae/tiam Constantinianas [1]on[g]a / vetustate corrupta(s) ex virib(us) suo / quam etiam E SABINIANEUS ORD / [---] REM filio VIACENI / RE statuam bene merenti patron / [p]ra[estan]tissimo (?) [---], / duoviro, senatus populusque Trebu/[lanus---] statuam decreverunt, / d(ecreto) d(ecurionum); see discussion in Solin, 1993, n. 9 and Carlà, 2009, 219.

${ }^{2}$ The other being $C I L$ X, $4560=L S A-1963$, to the Roman senator and local patron Ragonius Vincentius Celsus.

${ }^{3}$ To paraphrase Ward-Perkins, 2016, 35 (referring specifically to statues). On civic honours and city life, see Veyne, 1976 and Lendon, 1997; Ma, 2013, and Domingo Gygax, 2016, offer valuable insights
} 
cities of the Roman empire changed during Late Antiquity, so did the nature and functions of these signs of distinction, as well as the frequency with which they were awarded. The aim of this article is to analyse the evolution of the classical economy of honours - the varity of forms, the system of rules, and the diversity of agents involved in the bestowal of markers of social status - in the cities of late antique Italy. In order to do this, it will focus on two closely related sets of questions: what types of honours were bestowed in the late antique period, and in what contexts were they employed? More importantly, what groups were involved in this practice, whether as awarders or as honorands, and what does their involvement reveal about transformations in civic life? As I will argue, the analysis of the practice of bestowing civic honours shows a remarkable degree of popular participation in the municipal life of late antique Italy, proposing and dedicating distinctions to different members of the local and imperial elite. Popular groups did not operate in isolation, but often in conjunction with the city's ruling class (they too included in categories like populus and cives). In doing it, they helped to shape the late antique economy of honours, contributing to the affirmation of new political priorities that resulted in the legitimation of new actors in civic life. Together with municipal elites, popular groups maintained the tradition of bestowing signs of distinction relevant in the fourth century; their withdrawal from this practice led to a dramatic revolution in the working of civic honours. As I will show, the history of honorific dedications provides us with a precious insight into the inner working of urban communities in Late Antiquity.

Recent decades were marked by a growing scholarly interest for the role played by non-elite groups in late Roman society. Following the work of Evelyne Patlagean for the East and Michel Mollat for the West, recent years were marked by a renewed focus on the poor and their place in social and economic life. ${ }^{4}$ Alan Cameron and Charlottte Roueché examined the role of circus factions and acclamations in politics, stressing the importance of such forms of participation in late antique cities. ${ }^{5}$ For the cities of North Africa, Claude Lepelley considered the role of popular assemblies, and Julio Cesar Magalhães de Oliveira highlighted the active

into this practice in Hellenic contexts; Wallace-Hadrill, 1990 discusses developments in the Roman period.

${ }^{4}$ Patlagean, 1977; Mollat, 1978; more recently, Freu, 2007.

${ }^{5}$ Cameron, 1976; Roueché, 1984; Liebeschuetz, 2001, 203-220 discusses these developments in the context of the transformation of Roman cities. 
character of plebeian groups in its economic and social life. ${ }^{6}$ In the case of Italy, however, most studies have maintained their focus on the municipal notables, dealing primarily with institutional developments or the role of municipal and imperial elites in the peninsula; the populus is usually considered in the context of patron-client relations. ${ }^{7}$ And yet, as Jill Harries showed, popular groups remained important actors in Italian civic life, participating in traditional assemblies as well as voicing their opinions through acclamations. ${ }^{8}$ Building on Harries' argument, this article will use the evidence for the bestowal of civic honours as a form of exploring the complexity of municipal politics, showing how different groups (and not just curiales) participated in institutional life, playing a crucial role in the evolution of the classical city in late antique Italy.

The cities of the Italian peninsula and its islands are particularly suited for this type of study. ${ }^{9}$ Urban communities had a long history, and enjoyed the continued patronage of senators, emperors, and local notables throughout the imperial period including Late Antiquity. ${ }^{10}$ Recent archaeological work attests to remarkable continuities as well as important changes in the form and appearance of urban settlements. ${ }^{11}$ Perhaps more importantly, scholars working on this area benefit from an unequalled epigraphic record: tabulae patronatus and more significantly inscribed statue dedications provide important information for the award of civic honours, including their local institutional and historical contexts. ${ }^{12}$ This rich material can provide useful insights for our picture of city life in this period, offering valuable information about the extent and the form of involvement of popular groups in institutions and practices that had defined ancient cities for centuries.

\footnotetext{
${ }^{6}$ See Lepelley, 1979, 140-149; Magalhães de Oliveria, 2012; similar issues have been explored for the countryside: see Dossey, 2010 (for North Africa) and Grey, 2011.

${ }^{7}$ See, for example, the important studies of Ausbütel, 1988; Lepelley, 1992; and Cecconi, 1994. Words like populus and plebs are frequently lacking from the indexes of books on this topic.

${ }^{8}$ Harries, 2003. Lepelley, 1979, 140-149 explored some of these issues for North Africa.

${ }^{9}$ I will not consider Rome and its immediate surroundings of Ostia and Portus, because in these cases the presence of a powerful senatorial elite and of members of the court led to a very different social dynamic.

${ }^{10}$ See Ward-Perkins, 1984 for urban life in the North and centre of the peninsula. Ausbüttel, 1988, and Cecconi, 1994 provide overviews of the political and administrative realities. Marazzi, 2006, is a good overview of city life, and Delogu and Gasparri, 2010 covers different aspects of the history and archaeology of the area.

${ }^{11}$ See, for example, the studies collected in Ghilardi et al., 2006; Augenti, 2006; for the South, see Pugliese Carratelli, 1998. For provincial surveys, see, e.g., Savino, 2005, and Iasiello, 2007.

12 Witschel, 2001, provides a valuable overview of the evidence, with emphasis on inscriptions.

Witschel, 2006, surveys the epigraphy of Tuscia et Umbria. For statue dedications, see Machado, 2016.
} 
This article is divided into three sections. The first section will characterise the late antique economy of honours, highlighting the complex combination of traditionalism and innovation that marked this aspect of civic life. Section 2 will analyse the involvement of different groups in the production of honours, paying particular attention to the role of non-elite awarders in this practice. The final section will discuss the choices and priorities of urban communities in dedicating such signs of distinction, using the evidence from statue dedications to analyse the social identity of recipients of honours. As I will show, these point to important developments in local civic life, as well as to a complete subversion of the principles that had defined the classical economy of honours. I will return to these questions in the conclusion, considering the broader developments that helped to shape the evolution of civic life in late antique Italy.

\section{The late antique economy of honours}

Throughout antiquity, civic communities around the Mediterranean celebrated individuals who performed actions in their favour - whether their own citizens or not - by bestowing upon them different types of distinction. This 'Maussian' system of symbolic and material exchanges was a defining aspect of classical city life. ${ }^{13}$ Honours were proposed, voted, and awarded by the city or its legitimate political bodies and officials; they could also be decided by more specific groups, such as collegia and city regions, but always with the authorisation of the local authorities. Official honours could serve different functions, rewarding benefactors and displaying political loyalty; they could be immaterial, like honorific titles, or take a monumental form, like a statue; honorific monuments played an essential role in the definition of urban space, occupying, giving form and meaning to the public areas of ancient cities. ${ }^{14}$ By the end of the third century, Italian civic communities could rely on a long and complex tradition of bestowing civic honours - a fact attested to by the unusually rich epigraphic record available. ${ }^{15}$ The splendid collections of local and regional museums across modern Italy are the most eloquent testimonial to the vitality and dynamism of this system.

\footnotetext{
${ }^{13}$ Although Mauss, 1990 (or. ed. 1923-1924) has been frequently criticised, his work remains the main theoretical reference. See, besides the works cited above, the contributions to Wallace-Hadrill, 1989, Satlow, 2013, and Carlà and Gori, 2014.

${ }^{14}$ A point eloquently demonstrated by Alföldy, 1979; see more recently De Maria, 2017 (for the early empire); for Late Antiquity, see Smith, 1999 (for the East) and Witschel, 2007 (for the West).

${ }^{15}$ See Cooley, 2000A, and Gregori, 2008.
} 
This classical system of honours went through important changes during the late antique period, as a result of the broader transformations that redefined cities and urban life. This is more clearly visible in the case of acclamations and honorific statues, for which there is more abundant documentation, but titles and magistracies, with the privileges and authority that derived from them, remained important throughout our period. Here, as elsewhere, scholars of Late Antiquity frequently find themselves fighting against the tyranny of silence, arguing for the continuity of social practices in a period when the amount of evidence available is decreasing. This is the case of funerary monuments, for example. Municipal councils had traditionally granted special rights concerning the location and dimension of tombs, as a form of civic honour - a distinction recorded by the epigraphic formula l(ocus) d(atus) $d$ (ecreto) d(ecurionum). ${ }^{16}$ This form of distinction seems to have disappeared in the course of the fourth century, however, as the use of the formula became rarer and Christian funerary spaces (controlled by a different authority) gained prominence. Tombs remained important markers of social distinction and identity, but they were not part of the economy of honours anymore.

\section{Acclamations and civic honours}

It is probable that the most elusive form of public celebration in late antique cities was also the most common in this period: acclamations, the rhythmic chanting of words and verses to praise or criticise someone, which took place in gatherings such as political assemblies, games, and churches. Already a traditional form of political communication in the early imperial period, acclamations seem to have gained importance in Late Antiquity. ${ }^{17}$ Their oral nature did not reduce their importance in the eyes of local and imperial elites: in 331, Constantine issued an edict determining that acclamations praising or criticising officials should be recorded and transmitted to the court. ${ }^{18}$ As John Dillon suggested, this was part of a Constantinian effort to keep officials in check, establishing a direct line of contact with provincial populations - a policy that was followed by later emperors. ${ }^{19}$ The fact that they were

\footnotetext{
${ }^{16}$ See, for the Italian evidence, Milano and Pistarino, 2008.

${ }^{17}$ See CIL IV, 1094, 7343, and 7346 for early examples from Pompeii. For acclamations and their history, Roueché, 1984, remains essential reading; see also Chaniotis, 2009, and Hugoniot, 2002. Harries, 1999, 65-69 discusses acclamations as a form of political comunications at the level of the imperial government; see also Dagron, 2011 for the case of the Hippodrome in Constantinople.

${ }^{18}$ CTh 1.16.6, posted at Constantinople and addressed to the provincials.

${ }^{19}$ See Dillon, 2012, 122-136; also Cameron, 1976, 241. On later emperors, see Ando, 2000, 203-205.
} 
incorporated into official municipal documents, in fact, suggests that they were an integral part of the late antique economy of civic honours.

This is indicated by a tabula patronatus from Neretum, dated to 341, where it is recorded that the offer of the title of patron originated from the shouted requests of the populus (succlamante populo). ${ }^{20}$ Tabulae recording the offer of such titles occasionally register acclamatory formulae, such as "Helpidi, homo felix, Deus te serve!" in one such document from Paestum. ${ }^{21}$ A group of statue dedications from Lilybaeum (Sicilia) shows that this practice was also usual in other types of inscriptions: the opening of the text with expressions like "Cureti vivas!" and "Eumeni vivas!" seems to echo acclamations shouted during the meeting when the statue was awarded. ${ }^{22}$ This is more clearly the case in another dedication from the same city:

"Life to the Pompeiani! On account of his distinguished justice, and of his literary merits, and of the love which he placed not only on his fatherland but on the whole province; to Iulius Claudius Peristerius Pompeianus, of clarissimus rank, former governor of the province of Sicily; the whole council, in a splendid meeting, set up this statue to its worthy and most excellent patron. Life to the Amazonii!"23

The "splendid" meeting of the curia that voted the award provided a perfect setting for the acclamation of a former governor and patron of the city - with his family. Another inscribed statue dedication (this time from Puteoli in Campania), a verse inscription of clear Christian nature, illustrates how the populus could be involved in these celebrations:

[Statue of] Tannonius Crhysantius (sic), patron of clarissimus rank. Ever growing in his merits, the fame of the name of Crhysantius (sic) is celebrated by all the people

\footnotetext{
${ }^{20} C I L$ IX, 10=EDR 145422 .

${ }^{21} C I L \mathrm{X}, 478=E D R 135326$; see also $C I L I X, 259=E D R 163418$ and $A E 2004,443=E D R 153193$, and the observations of Parma, 2006, 203.

${ }^{22}$ Respectively, $C I L$ X, 7234 $=L S A-2065$ and $A E$ 1966, 167=LSA-2852. See also $A E 1916,102=L S A$ 1808 , from Regium Iulium in Calabria.

${ }^{23} A E$ 1906, 75b=LSA-2853 (transl. Gehn): "Pompeianis vita. / Ob insignem iustitiam / et merita litterarum et amore / quem non solum circa patriam / sed per omnem provincim (sic) conlocavit, / Iul(io) Cl(audio) Peristerio / Pompeiano, v(iro) c(larissimo), excons(ulari) p(rovinciae) S(iciliae), / universa curia in coetu splendidu suo / patrono digno et praestantissimo / statuam conlocavit. / Amazoniis vita."
} 
and councilors with their voices, [and] his fatherland assigns him bright honours with inscriptions. A destiny happy through the offspring of the man awaits you and yours for long years, looking forward to worthy grandchildren, and you highest God look to the family of Crhysantius (sic). ${ }^{24}$ (Emphasis added)

The inscription confirms, furthermore, the importance of acclamations as a form of honour in civic life. ${ }^{25}$ The reference to the celebration with the voices of councilors and people, as well as the vows of a "happy destiny" for Tannonius strongly suggest the occurrence of acclamations on the occasion of the vote that decreed the statue - a vote that took place in the presence of the populus and the patres; mentioning this distinction was relevant precisely because disagreement was possible. Negative acclamations, the voicing of disapproval of policies or politicians, would not have been inscribed in monuments like these, but they were also a possibility in local politics. This is why the approval and support of the populus (and other groups) deserved to be inscribed: it brought prestige and it could be used to further one's claim to power. Titles and offices were, in this sense, an even more obvious sign of social distinction.

\section{Honouring service}

Being elected to municipal magistracies and participating in the curia were, in themselves, a form of civic honour. ${ }^{26}$ Although united for being part of the city's elite, members of the ordo were a very diverse and hierarchical group. Distinction and privilege were defining components in municipal politics, especially at the top. Membership of the curia was gained through inheritance or by co-optation; curiales were elected to magistracies by their peers; and the high visibility that came with service (although not without costs) offered different opportunities for personal

\footnotetext{
${ }^{24}$ CIL 1813=LSA-1911 (transl. Gehn): "Tanno[ni] Crhysanti, (sic) v(iri) [c(larissimi)], / patroni. / Florentem meritis Crhy/santi (sic) nomine, famam / patria concelebrant cuncti / populique patresque vocibus / claros titulis consignat hono/res; teque tuosque manet / longos mansura per annos / felix prole viri dignos quesitu/ra nepotes ad tu summe deus / Crhysanti (sic) respice gente/m." I have incorporated the correction proposed by Camodeca, 2014, 126 for the integration of line 1.

${ }^{25}$ Popular acclamations were also relevant in ecclesiastical politics. See Harries, 2003, 135-138, for Italy; Hugoniot, 2002, for North Africa.

${ }^{26}$ Ausbüttel, 1988, 22-27 and Cecconi, 1994, 171-181 argue for great continuity of these institutional arrangements.
} 
celebration. ${ }^{27}$ This is demonstrated by the continued use of expressions like omnibus honoribus functo in honorific dedications: having completed service was a source of distinction. ${ }^{28}$ The dedication of a statue in Ocriculum (Tuscia et Umbria), probably in the late fourth century, records the honorand's successful local career: Caius Volusius Victor was quaestor, duumvir, aedilis, IIIIvir iure dicundo, and IIIIvir quinquennalis. ${ }^{29}$ Another example from Interamna Lirenas, datable to the early fifth century, honoured a leading notable (primarius) who fulfilled all the offices of the city and of the curia. ${ }^{30}$ The most successful notables could be appointed curatores rei publicae, an imperial appointment that confirmed a local choice. ${ }^{31}$ Civic honours played thus an important role in consolidating and making visible the internal hierarchies that defined the ordo, responding to factors like ancestry, wealth, service, or commitment to the public good. Local notables, Roman senators, and imperial officials could also be co-opted as patrons, a title that implied in a specific form of relationship, as we will see below; being a patron was prestigious in itself, and this honour was made concrete by the production and setting up of inscribed tabulae patronatus in bronze, a monument exposed in public and domestic settings. ${ }^{32}$

The appearance of traditional municipal titles in honorific inscriptions is a remarkable indication of the vitality of civic life in our period. Some, like the duumvirate, referred to old and specific Roman traditions. Others, like sacerdotales and coronati, responded to the changed realities of the late antique state, identifying those chosen to represent the city in the provincial council. Others still could celebrate local religious or ethnic identities. This is well illustrated by a statue dedication from Clusium (Tuscia et Umbria), probably from the first half of the fourth century:

\footnotetext{
${ }^{27}$ See Jones, 1964, 724-731 and 737-757 remain essential; see also Liebeschuetz, 2001, 124-136 and Cecconi, 2006.

${ }^{28}$ E.g., $C I L$ XI, 4096=LSA-1632; CIL X, 1805=LSA-1917; AE 1983, 196=LSA-341; AE 1919, 71=LSA2568; and CIL X, 4755=LSA-1972.

${ }^{29}$ CIL XI, 4094=LSA-2682: "Caio Volusio Victori, qu(a)estori r(ei) p(ublicae) Oc/riculanorum, IIII/viri (sic) aediles (sic), IIIIviri (sic) iur/e ed(i)c(undo) (sic), IIII(viro) quinq(uennali), cives ei (sic) / plebei hoc emerito stat/uam huic posuerunt, q/ui $t(h)$ ermas (h)iemalis ad pristi/nam dig(nitatem) restauravit et d(e)d(i)c(a)v(it).”

${ }^{30}$ CIL X, 5349=LSA-2030: “...primario civitatis / nostrae, omnibus honoribus et honoribus cu/riae suae perfuncto...".

${ }^{31}$ On curatores rei publicae, see the essential studies of Camodeca, 1980, updated in 2008B, and Jacques, 2018 (or. ed. 1984). Lepelley, 1979, 168-193 remains the basic reference for our period. ${ }^{32}$ For patrons, see Krause, 1987; for tabulae patronatus, see Harmand, 1957, 334-338 and Nicols, 1980; for late antique Italy, see Buonocore, 1992.
} 
"[Statue of] Honorius. To Lucius Tiberius Maefanas Basilius, of egregius rank, former praetor of the Fifteen Peoples (ex praetoribus XV populorum), defender of the council and citizens, decurialis of the eternal City; because he governed faithfully and with integrity his citizens and the people of Clusium, cherished them with love, raised them through [his] generosity, [and] fostered them with his kindness. And so, as a reward for his good deeds, everyone, at the urgent request of all, have offered [this statue]. $" 33$

Claude Lepelley suggested that the praetor $X V$ populorum Etruriae was, by this date, a priest of the imperial cult active in the provincial assembly. ${ }^{34} \mathrm{He}$ would exercise, in this case, the same function as the coronatus Tusciae et Umbriae, known from contemporary inscriptions, but this cannot be proved. ${ }^{35}$ The praetor $X V$ populorum was an ancient office, possibly of ethnic/Etruscan origins, that is attested throughout the imperial period. ${ }^{36}$ An inscription from Volsinii, most likely datable to the fourth century, refers to a praetor (his name is lost) who was also curator of the city's ancient temple of Nortia (an important Etruscan goddess), reinforcing the idea that if the praetor was associated with the imperial cult by this date, he nevertheless still retained an important role in the way regional traditions were celebrated. ${ }^{37}$

Participation in festivals and spectacles, and especially their sponsorship, could also be turned into a form of civic honour. In Interamna Lirenas, for example, a late imperial inscription records that a member of the local elite was awarded a bisellium, a large and conspicuous seat in the orchestra of the theatre, as a reward for his services. ${ }^{38}$ Although this was an usual form of honour in classical times, this is the only late antique Italian inscription to refer to it. ${ }^{39}$ As Violaine Malineau showed, there is plenty of evidence for the restoration of theatres in different parts of Italy, and

\footnotetext{
${ }^{33}$ CIL XI, 2115=LSA-1623: "L(ucio) Tiberio Maefanati Basi/lio, v(iro) e(gregio), ex praetoribus XV pop(ulorum), / defensori ordinis et civium, / decuriali Urbis aeternae, / ob hoc quod fide cives suos / populumq(ue) Clusinum integritate / gubernarit, amore dilexerit, / largitate sublebarit, humani/tate foverit, pro merito ergo benefi/ciorum universi statuam lae/tantes votis omnibus obtulerunt."

${ }^{34}$ Lepelley, 1992, 360.

${ }^{35}$ CIL XI, 5283=LSA-1638, from Hispellum; EDR 135070 from Carsulae.

${ }^{36} A E$ 1998, 459=EDR077942 (Rusellae, AD 70-150); CIL XI, 1941=EDR143087 (Perusia, 71-100); $C I L$ XIV, 5345=EDR110163 (Ostia, 180-184); CIL XIV, 172=EDR146349 (Ostia, 184); CIL XI, 2699=EDR145247 (Volsinii, 3rd c.); CIL XI, 5170=EDR125668 (Vettona, 4th c.). See Liou, 1969, with observations of Torelli, 1995 (or. ed. 1971); more recently, Zuddas, 2017.

${ }^{37}$ CIL XI, 7287=EDR071982; see Zuddas, 2017, 225, for this dedication. For the cult of Nortia and its importance as a marker of identity, Machado, 2009, 335-341.

${ }^{38}$ CIL X, 5348=LSA-2029; dates suggested for this inscription vary from the third to the early fifth century, see Fagan, 1999, 271.

${ }^{39}$ See, on bisellia, Sear, 2006, 6; see also the remarks of Rawson, 1987, 107-110.
} 
games and spectacles remained important occasions in the calendar of the cities of this period. The disappearance of references to bisellia and biselliati is particularly puzzling when we consider how closely related were games and honours. This is further illustrated by the Constantinian rescript to Hispellum, which granted to the city the right to organise a provincial festival with theatrical displays and gladiatorial games in association with the imperial celebrations at the nearby temple of the gens Flavia. ${ }^{40}$ The performance of the games and festival served as an occasion for the celebration of Caius Matrinius Aurelius Antoninus, provincial priest in the middle of the fourth century.

"To Caius Matrinius Aurelius Antoninus, son of Caius, of the Lemonia tribe, of perfectissimus rank, coronatus of Tuscia et Umbria, priest of the family of the Flavians, sponsor of most abundant spectacles and of extraordinary rejoicing in the theatre, aedilis, quaestor, twice member of the board of two with judicial powers for five years of this most splendid colonia, curator of the city, and first principalis; on account of the services of his kindness towards it, the whole urban plebs of Flavia Constantia (Hispellum) [set this up] to a most worthy patron." ${ }^{\prime 1}$

The inscription records the reason for the dedication of the statue, the organisation of games, before listing Antoninus' cursus honorum, indicating the importance of his benefactions for his fellow citizens. It is notable, in this case, that the dedication of such an important award was carried out by the plebs of Hispellum an issue that will be discussed in more detail in the next section.

\section{Honorific monuments}

Different types of monuments were awarded as honorific signs. Paolo Liverani has recently highlighted the importance of painted portraits as a form of celebrating personal power, showing how paintings (whether on walls or wood) had been a

\footnotetext{
${ }^{40}$ CIL XI, 5265=EDR136860; see Cecconi, 2012, and Lenski, 2016, 114-130 for recent discussions of the text and the festival.

${ }^{41}$ CIL XI, 5283=LSA-1638: C(aio) Matrinio Aurellio, / C(ai) f(ilio), Lem(onia), Antonino, v(iro) $\mathrm{p}$ (erfectissimo), / coronato Tusc(iae) et Umb(riae), / pont(ifici) gentis Flaviae, / abundantissimi muneris sed et / praecipuae laetitiae theatralis ẹdịtorị, / aedili, quaestori, duumviro / iterum q(uin)q(uennali) $\mathrm{i}$ (ure) d(icundo) huius splendissimae / coloniae, curatori r(ei) $\mathrm{p}$ (ublicae) eiusdem / colon(iae) et primo

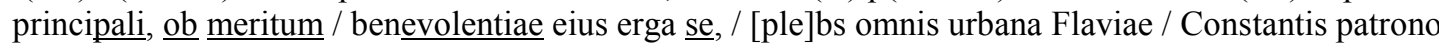
/ dignissimo.
} 
common feature of Roman cities since earlier periods. ${ }^{42}$ Although material evidence for painted honorific portraits from the imperial period is poor (at best), literary references make it clear that these were abundant. Fronto observed, in a letter to the emperor Marcus Aurelius, that painted portraits of the emperor could be found everywhere, in shops, workshops, porticoes, passageways and windows. ${ }^{43}$ Painted portraits were a usual form of celebration of imperial power, being sent to provinces (and co-emperors) at the time of imperial accession: it was the vision of the image of Constantine that prompted Maxentius to claim the throne in Rome, according to Zosimus, and Lactantius notes that Constantine removed the statues and the portraits of Maximian after the old emperor fell from grace. ${ }^{44}$ Painted portraits of members of the Italian elite were on display in the catacombs of S. Gennaro in Naples, for example, in the fifth and sixth centuries. ${ }^{45} \mathrm{~A}$ number of poems in the Greek Anthology record the existence of painted portraits of imperial officials used as a form of honour in places like Ephesus and Constantinople, but there is no information of this type for Italy. ${ }^{46}$

However, some evidence suggests that local Italian communities did resort to paintings as a form of civic honour. As a fragmentary inscription on a statue base (now lost) seen in Aquinum (Campania) records: “...had benefitted. To this man for whom the entire populus of Aquinum determined that a bronze patronage table should be offered, and that an eternal statue should be erected in this place (together?) with his painted portrait for (his) perpetual memory." 47 As Ignazio Tantillo observed, the inscription records different honours offered by the populus to an unknown benefactor (whose name does not survive), showing not only that these could be combined, but also that they could include painted portraits. ${ }^{48}$

More than paintings, the inscription from Aquinum also shows that honorific statues were the most durable form of honour awarded by civic communities in late antique Italy. In the vast majority of cases, these monuments were accompanied by an

\footnotetext{
42 Liverani, 2016 and 2018.

${ }^{43}$ Fronto, Ep. 4.12.4.

${ }^{44}$ Zosimus, 2.9.2; Lactantius, De Mortibus Persecutorum 42.1.

${ }^{45}$ Bisconti, 2015, 43-45.

${ }^{46}$ See Mango, 1986, 118-119, with discussion in Liverani, 2016, 326-328.

${ }^{47}$ CIL X, 5426=LSA-2031: “------ / [---] iuvaberit. / Huic populus / Aquinatium tabulam / aeneam patronatus tra/ditam sed et statuam / perpetuabilem cum pic/turam (sic) similitudinis / eius hoc in loco ad peren/nem (sic) testimonium censuer(unt) / constituendam." See Tantillo, 2017.

${ }^{48}$ It is possible, although unlikely, that "statuam ... cum picturam ( $\mathrm{sic}$ ) similitudinis eius" refers to a single, painted statue: Tantillo, 2017, 627-630.
} 
inscribed base recording the identity of the honorand, the awarder, and the reasons for the dedication. There were exceptions, like shield portraits and busts, but the context and nature of these exceptional forms is, in the case of Italy, nearly always impossible to determine. ${ }^{49}$ The power of honorific portraits is evoked in the passage of Rutilius Namatianus' account of his journey from Rome to Gaul in which he describes his visit to the forum of Pisa: there he saw the image of his father, the inscription with his cursus honorum and the dedication, a monument that brought tears to his eyes and that reminded the Pisans of their mutual affection. ${ }^{50}$ By combining inscription and sculpture, statues were efficient markers of social and political distinction. As R. R. R. Smith pointed out, "[w]ithout the inscription, the statue became an ornament. (...) Without a statue, the inscribed base was merely a civic record." 51

It is unfortunate, in this sense, that most of the evidence available for Italy consists of the inscribed bases only, as the statues that once accompanied them are now mostly lost. The Last Statues of Antiquity ( $L S A)$ database records 408 pieces of evidence for statues set up in Italy - excluding Rome, Ostia, and Portus - during the late antique period (not all of these honorific). These include 64 statues and fragments, 341 inscriptions, and three textual references. ${ }^{52}$ They are unevenly distributed across the peninsula, with a large concentration in Campania and particularly low numbers in Sardinia, Alpes Cottiae, and Aemilia et Liguria (Table 1).

\begin{tabular}{|l|c|c|c|c|}
\hline Province & Statues & $\begin{array}{c}\text { Textual } \\
\text { references }\end{array}$ & Bases & Total \\
\hline Sardinia & 0 & 0 & 5 & $\mathbf{5}$ \\
\hline Alpes Cottiae & 0 & 0 & 3 & $\mathbf{3}$ \\
\hline $\begin{array}{l}\text { Aemilia et } \\
\text { Liguria }\end{array}$ & 2 & 0 & 29 & $\mathbf{4 5}$ \\
\hline $\begin{array}{l}\text { Venetia et } \\
\text { Histria }\end{array}$ & 16 & 0 & $\mathbf{2 1}$ \\
\hline $\begin{array}{l}\text { Flaminia et } \\
\text { Picenum }\end{array}$ & 4 & 2 & 31 & $\mathbf{3 7}$ \\
\hline $\begin{array}{l}\text { Tuscia et } \\
\text { Umbria }\end{array}$ & 5 & 1 & 172 & $\mathbf{1 9 3}$ \\
\hline Campania & 21 & 0 & 24 & $\mathbf{2 9}$ \\
\hline Samnium & 5 & 0 & 25 & $\mathbf{2 9}$ \\
\hline $\begin{array}{l}\text { Apulia et } \\
\text { Calabria }\end{array}$ & 4 & 0 & 16 & $\mathbf{1 8}$ \\
\hline Lucania et Brittii & 2 & & & \\
\hline
\end{tabular}

\footnotetext{
${ }^{49}$ See Smith, 2016, 9-11. The situation was different in the East, such as in Aphrodisias: Smith, 1990.

${ }^{50}$ Rutilius Namatianus, De Reditu suo, 1.575-590.

${ }^{51}$ Smith, 2016, 3.

${ }^{52}$ For a preliminary discussion of this material, see Machado, 2016. The numbers presented here are updated and include adjustments to the database.
} 


\begin{tabular}{|c|c|c|c|c|}
\hline Sicilia & 5 & 0 & 19 & 24 \\
\hline
\end{tabular}

Their sheer number makes statues - and especially their bases - the richest type of evidence available for the study of civic life, reflecting the variety of situations and the reasons for which they were awarded. The numerical significance of statue monuments is enhanced by the fact that a large proportion of this material (more specifically the inscriptions) can be dated with some certainty. In this respect, it is possible to trace not only the geographic distribution of statues, but also their evolution over time. ${ }^{53}$ The number of datable dedications in Italy declined in the course of the fourth century, after having peaked during the Tetrarchic period (an average of 3.7 bases per year); it fell by nearly $50 \%$ in the subsequent period, remaining stable until c. 380 (1.8 bases per year), when it fell dramatically until its virtual disappearance in the fifth century. ${ }^{54}$ Although it is impossible to document it, this decline seems to have involved other forms of civic honours too, or at least the evidence for their award. If this is correct, this is the most significant element in the late antique history of civic honours, and it is necessary to consider how this change was related to the broader transformations of civic life that took place in this period.

\section{The social production of honours}

The award of a civic honour was not an isolated or spontaneous decision. It followed established social practices and norms, requiring a political decision by the civic community, an official agent or a group accepted by it. Tabulae patronatus and inscribed statue bases record useful information about how these decisions were made. A number of tabulae register the decision by the decurions, convened in the city's curia. ${ }^{55}$ Motions were usually proposed by a leading member of the ordo, a strategy that probably brought greater weight to it. These could be quinquennales, duumviri, or principales, according to the local structure of power. ${ }^{56}$ A good example is the table recording the co-optation of Caius Sallius Pompeianus Sofronius as patron

\footnotetext{
${ }^{53}$ See detailed discussion in Machado, 2010, and especially 2016.

54 These numbers exclude Rome and its surroundings.

${ }^{55}$ E.g., CIL X, 476=EDR122208; CIL X, 477=EDR157430; AE 2004, 443=EDR153193; AE 1937, $120=$ Supplit 9 (1992), n. 34.

${ }^{56}$ CIL IX, 259=EDR163418 (quinquennales); CIL X, 476=EDR122208 (duumviri); $A E 1937$, $120=$ SupplIt 9 (1992), n. 34 (principales); probably also $A E 2004,443=E D R 153193$ (too damaged to be certain).
} 
of Amiternum (Flaminia et Picenum). ${ }^{57}$ The meeting in which the title was awarded took place at the curia Septimiana Augustea on 7 December 325, with enough decurions in attendance to make the decision valid. The tabula records the content of the motion, put forward by the principales Atrius Arrenianus and Vergilianus Albinus, as well as the final decree of the assembly, registered by Antistius Lucentius, probably also a secretary of the curia. ${ }^{58} \mathrm{We}$ are thus informed by an official document (that doubled as a monument) about the formalities of such political occasions.

Other tabulae record the populus or the cives as responsible for the proposal and decision, also in an assembly. ${ }^{59}$ This is explicitly mentioned in one such document from Paestum (Lucania et Brittii), datable to 347, co-opting Aquilius Nestorius and his son, Aquilius Aper: "The citizens of the colonia of Paestum convened in a fully attended assembly, held a debate and passed the following resolution (...)". ${ }^{60}$ Scholars frequently minimise the significance of these texts, relegating cives and populus to a subordinate role and arguing that they acted under the instruction of the curia. In the case of Nestorius' tabula, for example, its editor suggested that the reference to citizens was incorrect, as the inscription should have referred to decuriones instead ("il termine tecnico"). ${ }^{61}$ There is no real reason for downplaying popular agency in this way. As Harries argued, the table from Paestum shows instead the insistence of the populus in recording their own initiative, an interpretation that is supported by the existence of another tabula, dated to the same day (1 August 347), recording a similar initiative by the members of the Curia. ${ }^{62}$ Further information is provided by another such document, advertising the decision to co-opt Sofronius iunior (whose father was co-opted by the curiales), from Amiternum: the inhabitants of the vicus of Foruli gathered in a ceremonial banquet in honour of the emperor (in [e]pulo Aug(usteo)), where their procurator Antistius Lucentius made the proposal. ${ }^{63}$ Besides being procurator, Lucentius had been

\footnotetext{
${ }^{57}$ See $A E$ 1937, $120=$ SupplIt 9 (1992), n. 34; see also Goddard, 2002, and Salomies, 2015, for useful discussions of the text.

${ }^{58}$ Goddard, 2002, 1037. Cecconi, 1994, 196, suggests "un membro della classe artigiana".

${ }^{59}$ E.g., CIL IX, 10=EDR145422; CIL X, 478=EDR135326; AE 1990, 211=EDR081748; AE 1992, 301. Although not a tabula, CIL X, 5426=LSA-2031 also records the involvement of the populus in the offering of one.

${ }^{60} A E$ 1990, $211=E D R 081748$, 11. 3-4 (transl. Harries, 2003, 140): "Cum cibes frequentes coloniae Paestanorum in uno adfuissent, consilioque habito, berba fecerunt (...)”.

${ }^{61}$ Sabbatini Tumolesi, 1990, 239; see also Parma, 2006, 206. Harries, 2003, collects other examples.

${ }^{62} C I L \mathrm{X}, 477=E D R 157430$, but in this case referring only to Nestorius.

${ }^{63}$ See SupplIt 9 (1992), n. 35, 11. 3-4, correcting AE 1937, 121 's suggestion of in [tem]pulo Aug(usti). See also Goddard, 2002, 1032, n. 29.
} 
involved as notary in the production of the tabula of Sofronius senior, and his association with the family might explain his leadership among the Forulani and his motivation for making the proposal.

The role of popular assemblies in the municipal life of the later empire is not clear. The decline of elections during the first centuries of the empire led to a redefinition of these political gatherings in local political life, in Italy and elsewhere. As Lepelley observed for the cities of North Africa, the surviving imperial legislation acknowledges circumstances in which the people participated in the selection of civic municipal magistrates, but through acclamation and expressions of approval and not through vote. ${ }^{64}$ Assemblies remained the best occasion for public discussion of civic issues and for the expression of approval or disapproval of policies and officials through acclamation. Suggesting a new patron and requesting the award of such an honour - to the point of commissioning a bronze tabula - would fit this picture very well.

A statue base from Amiternum illustrates the type of reaction that such civic honours could elicit from their recipients. Although the main text of the dedication is now lost, an inscription on the side of the monument records that the honorand presented the plebs of the city with food and drink for a banquet as a sign of gratitude, as well as with funds for similar celebrations in the future. ${ }^{65} \mathrm{~A}$ civic honour was the result of a complex political transaction that led to a variety of responses - frequently positive, but occasionally negative too. This is illustrated by another tabula patronatus from Paestum, dedicated by the ordo with all due formalities in 337 to Aurelius Gentianus, of equestrian rank. ${ }^{66} \mathrm{~A}$ few years later, Gentianus' name was erased, and (we don't know how long after) the back of the tabula was reused for another curial decree, conferring the title of patron to Aquilius Nestorius in $347 .{ }^{67}$ Nothing is known about Gentianus, but his case highlights the crucial political dimension of honours, awards that in theory were meant to last forever, but that could be cancelled by the curia. ${ }^{68} \mathrm{We}$ have no similar example of the title of patron being cancelled by the populus, but this possibility should not be ruled out. A large

\footnotetext{
${ }^{64}$ Lepelley, 1979, 142-146, citing CTh 12.5.1 (from 325) and 11.7.20 (from 412).

${ }^{65}$ CIL IX, 4215=LSA-1787, with the consular date of AD 338.

${ }^{66}$ CIL X, 476=EDR122208; the name of one of the consuls, Flavius Felicianus, and of one of the duumviri who proposed the motion were also erased.

${ }^{67}$ CIL X, 477=EDR157430.

${ }^{68} \mathrm{He}$ might be identified as the nutritor of the clarissima puella Caia Vettia Grata, mentioned in her sarcophagus (CIL X, 648=EDR116555 from Salernum): see Camodeca, 2013, 253 n. 66.
} 
proportion (if not the majority) of surviving inscribed bases for honorific statues was reused in late antique Italy, many in new dedications offered by popular groups and associations. ${ }^{69}$ Although it would be impossible to prove that any of these originated from monuments awarded to honorands that later fell from grace, this possibility cannot be completely ruled out.

The political decision to award a civic honour did not end in a vote: it was still necessary to pay for its bestowal or dedication. In a few cases, the inscriptions record the individual or group responsible for such actions. Patrons and benefactors had traditionally paid for the statues dedicated to them by cities and assemblies. It was a form of sparing clients and communities from extra costs, and at the same time yet another opportunity for displaying generosity. ${ }^{70}$ In Canusium (Apulia et Calabria), Lucius Annius Rufus paid for the statue dedicated by the populus. Another such monument from Interamna Nahars was paid for with funds collected by the awarders, whereas the costs of producing and inscribing a tabula patronatus from Genusia were covered by the local principales. ${ }^{71}$ It is reasonable to assume that when an inscription records that the honour was supervised by a specific official, such as a governor or a curator, funding was provided by his office or by him personally (more likely in the case of curatores). ${ }^{72}$ In most cases, however, the inscription does not offer further clues, and it is probable that the costs were paid for by the awarders themselves. It is necessary, therefore, to consider who were the agents involved in these dedications.

\section{Political participation in late antique Italy}

Although it is impossible to reconstruct the political reasoning behind each honour, the evidence from statue dedications allows us to explore the broader social dynamics that informed each decision. Throughout Italy, different agents were active in the setting up of statues, attesting to a very broad range of participants in municipal life. Not all awarders were directly involved in local civic life, but they contributed to the shape of Italy's economy of honours all the same. It is the case of the praetorian

\footnotetext{
${ }^{69}$ See the appendix in Machado, 2017: 353-357.

${ }^{70} \mathrm{See}$, of a long dossier of early imperial inscriptions, CIL V, 4416=EDR090209 (honore contentus inpendium remis[it]), 7008 (honore contentus impensam remisit); $C I L \mathrm{X}, 6018=E D R 129381$ (remissa pec(unia) publ(ica)), 7352=EDR127535 (impensa pub(lica) remissa); CIL IX, 669=EDR085810 (remisso r(ei) p(ublicae) sum[p]t[u]); cf. references in Liebenam, 1967, 128 (with n. 1).

${ }^{71}$ CIL XI, 4180=LSA-1635 (statue); CIL IX, 259=EDR 163418.

${ }^{72}$ E.g., CIL XIV, 2919=LSA-1684; CIL IX, 1561 $=L S A-1724$; CIL IX, 2639=LSA-1777; and CIL X, $1247=L S A-1868$.
} 
prefects Iulius Asclepiodotus and Aurelius Hermogenianus, who dedicated a statue to Constantius I in Brixia (Venetia et Histria), in $296 .^{73}$ A praepositus fabricae dedicated a statue to Constantine in Ravenna (Flaminia et Picenum), and the governor of Lucania et Brittii celebrated the emperor's mother Helena, in Salernum. ${ }^{74}$ Other dedications could have a more personal character, involving members of the same family or personal dependents: for example, a group of clients dedicated a statue to the Roman senator Virius Lupus, curator of Laurentum and Lavinium (Campania) in the early fourth century. ${ }^{75}$

The largest number of dedications, however, was carried out by local awarders (curatores rei publicae, city councils, popular assemblies, collegia, and city regions), who were responsible for 201 out of 344 dedications, and these are the ones that interest us here (Table 2).$^{76}$ These demonstrate the vitality of municipal life in the fourth century, as well as the attachment of these communities to traditional forms of participation and civic honours. The essential dynamics that characterised the relationship between local groups and their leaders in earlier periods continued in place, although not in every Italian province: it is necessary to take into account the wide geographical variations shown in Table 2.

\begin{tabular}{|c|c|c|c|c|c|c|c|}
\hline Province & $\begin{array}{c}\text { Local } \\
\text { awarders }\end{array}$ & Governors & $\begin{array}{c}\text { Private } \\
\text { awarders }\end{array}$ & $\begin{array}{c}\text { Imperial } \\
\text { officials }\end{array}$ & Emperors & $\begin{array}{c}\text { Unknown } \\
\text { awarders }\end{array}$ & Total \\
\hline Sardinia & 0 & 5 & 0 & 0 & 0 & 0 & 5 \\
\hline $\begin{array}{c}\text { Alpes } \\
\text { Cottiae }\end{array}$ & 2 & 0 & 0 & 0 & 0 & 1 & 3 \\
\hline $\begin{array}{c}\text { Aemilia et } \\
\text { Liguria }\end{array}$ & 2 & 0 & 0 & 0 & 0 & 1 & 3 \\
\hline $\begin{array}{c}\text { Venetia et } \\
\text { Histria }\end{array}$ & 9 & 9 & 2 & 2 & 1 & 6 & 29 \\
\hline $\begin{array}{c}\text { Flaminia } \\
\text { et }\end{array}$ & 10 & 1 & 0 & 2 & 0 & 3 & 16 \\
Picenum & 21 & 1 & 0 & 2 & 0 & 8 & 32 \\
\hline $\begin{array}{c}\text { Tuscia et } \\
\text { Umbria }\end{array}$ & 112 & 23 & 7 & 2 & 1 & 27 & 172 \\
\hline Campania & 15 & 1 & 0 & 0 & 0 & 8 & 24 \\
\hline Samnium & 15 & 11 & 0 & 0 & 0 & 3 & 25 \\
\hline $\begin{array}{c}\text { Apulia et } \\
\text { Calabria }\end{array}$ & 11 & 3 & 0 & 0 & 0 & 3 & 16 \\
\hline Lucania & 10 & & & & & & \\
\hline
\end{tabular}

\footnotetext{
${ }^{73} A E$ 1987, 456=LSA-1603 (with an useful discussion by U. Gehn).

${ }^{74}$ Respectively, $C I L$ XI, $9=L S A-1611$ and $C I L$ X, 517=LSA-1847.

${ }^{75}$ CIL XIV, 2078=LSA-1675.

${ }^{76} \mathrm{I}$ am here considering inscribed bases and textual references, as these provide the relevant information.
} 


\begin{tabular}{|c|c|c|c|c|c|c|c|}
\hline et Brittii & & & & & & & \\
\hline Sicilia & 9 & 7 & 0 & 1 & 0 & 2 & 19 \\
\hline Total & 201 & 61 & 9 & 9 & 2 & 62 & 344 \\
\hline
\end{tabular}

Table 2: Statue dedications in Italy: awarders

In places like Sardinia, Alpes Cottiae, and Aemilia et Liguria, the number of statues documented is simply too low to allow any generalisation. This cannot be due solely to the disappearance of the evidence, however, and it indicates that the practice of bestowing this particular form of civic honour was weaker here than in other parts of Italy. This is particularly puzzling in the case of Aemilia et Liguria, where the city of Milan (one dedication recorded) served as residence of the imperial court for a few decades between the end of the third and the end of the fourth century. During the early imperial period, emperors had come to play a prominent role in the economy of honours of Italian cities, as members of successive dynasties were commemorated in statuary form in fora and other public complexes, and proximity with the court was a powerful motivation for such initiatives. The case of Milan is made more striking precisely because this principle still continued in Late Antiquity. A useful contrast is Aquileia (Venetia et Histria), where four dedications to Constantine and his sons probably reflect the presence of emperors in the area. More importantly to our purposes the statue habit was primarily an affair under the control of local awarders, in spite of the importance of external agents like governors.

A letter of the Roman senator Quintus Aurelius Symmachus to his father, datable to 375 , attests to the involvement of civic groups in different forms of celebration, as well as making clear the reasons why they did it. ${ }^{77}$ In this letter, Symmachus describes his visit to Beneventum, a city that had recently been damaged by an earthquake. There, he wrote, he was received with the applauses and honours of the citizens, to the point of being weighed down by obligations, and the commitment of the local elite (maiores) with culture, tradition, and the beauty of the city left a pleasant impression. ${ }^{78}$ The Roman senator paints a picture of great vitality of civic life, and shows the use of civic honours as a form of generating obligations for honorands. It is unfortunate, in this context, that no inscription celebrating Symmachus survives from Beneventum (or from anywhere outside Rome), as this

\footnotetext{
${ }^{77}$ Symmachus, Ep. 1.3; see, on the earthquake and its aftermath, Torelli, 2002, 271-277.

${ }^{78} \mathrm{Ep}$. 1.3.3: "Ibi summo cultu civium plausuque susceptur tanto honore celebrabar, ut iam gravarer officiis".
} 
would give a useful insight into how the relationships between local communities and senators were developed.

It is worth following Symmachus' lead, considering in more detail the case of Campania, where local awarders were responsible for approximately $65 \%$ of all documented dedications in Italy. This should come as no surprise: besides being densely urbanised and having remained relatively prosperous for most of the late antique period, the cities of Campania maintained strong links with Rome and its senatorial elite. ${ }^{79}$ Furthermore, as the Roman senator also noted, different groups were involved in such dedications (Table 3).

\begin{tabular}{|l|c|c|c|c|c|c|c|}
\hline Awarder & $\mathbf{2 8 0 - 3 1 2}$ & $\mathbf{3 1 2 - 3 3 7}$ & $\mathbf{3 3 7 - 3 7 9}$ & $\mathbf{3 7 9 - 4 0 8}$ & $\mathbf{4 0 8 - 4 5 5}$ & Uncertain & Total \\
\hline $\begin{array}{l}\text { Popular } \\
\text { assemblies }\end{array}$ & 2 & 1 & 3 & 3 & 2 & 5 & 16 \\
\hline $\begin{array}{l}\text { City region } \\
\text { or collegium }\end{array}$ & 4 & 1 & 10 & 0 & 0 & 7 & 22 \\
\hline Ordo & 6 & 5 & 2 & 2 & 2 & 6 & 23 \\
\hline $\begin{array}{l}\text { Ordo et } \\
\text { populus }\end{array}$ & 5 & 6 & 6 & 6 & 3 & 9 & 35 \\
\hline Local official & 5 & 0 & 1 & 0 & 0 & 2 & 8 \\
\hline Res publica & 5 & 3 & 0 & 0 & 0 & 0 & 8 \\
\hline Total & 27 & 16 & 22 & 11 & 7 & 29 & 112 \\
\hline
\end{tabular}

Table 3: Local dedications in late antique Campania, divided by period.

Six cities, identified as Res Publicae, were responsible for eight dedications: Surrentum, Nola, Teanum Sidicinum, Fabrateria vetus, Formiae, and Minturnae (three dedications). Eight dedications were carried out by local officials, either curatores rei publicae (six dedications) or priests (two dedications, one in conjunction with the populus). The fact that none of the recorded dedications was carried out by a traditional municipal magistrate (such as duumviri or quinquennales), but by officials overseeing local affairs on behalf of the imperial government, is revealing of the broader political and administrative changes of the period: most of their dedications honoured emperors (four out of six). As we can see in Table 3, the ordines of various cities were intensely involved in awarding civic honours, be it independently or in conjunction with the populus. Curiales were members of the populus, and the fact that they could operate in agreement is far from surprising; what is striking, however, is

\footnotetext{
${ }^{79}$ Savino, 2005, is useful for the history of the area, including a survey of the social and economic history of its sub-regions in Late Antiquity (pp. 155-248). Camodeca, 2010, provides a good overview of the urban history of the area based on its epigraphy. For the close likes between Campania and Rome, see Camodeca, 2008A.
} 
that both political institutions should be named in these dedications. By opening the decision to grant an award to other segments of local society, curiales were actively seeking to increase support for their political choices. We must consider in greater detail, in this case, the role of popular participation in the late antique economy of honours.

\section{Popular politics}

As the information presented in Table 3 shows for Campania, different nonelite groups were active in the dedication of statues, and the same is true for most other provinces in Italy. Members of a city's political elite also participated in associations like the populus, collegia, and city regions (although not necessarily the plebs), and we can reasonably assume that they retained an influential voice among their lesser peers. And yet, groups beyond the curia were directly engaged in late Italian city life, being named in 73 out of 112 statue dedications in Campania. ${ }^{80}$ They played an important role in the legitimation of their elites, and their involvement in the bestowal of civic honours is a clear demonstration of this fact. This is illustrated by an inscription from Casinum (in Campania):

"[Statue of] Caius Paccius Felix. To Caius Paccius Felix, patron, who performed all offices and functions, son of Caius Paccius Felix, patron of the colonia of Casinum, by whose immense benefactions the fatherland, enriched, is recognised; to the curator rei publicae, by whose foresight we were always happily governed; to the curator and founder of public buildings, whose efforts and care and with whose own funds, after a series of years, the baths of Novianus were restored for our use; on account of all these works that he showed to his fatherland and citizens, the whole people of the colonia of Casinum, together with our children (universus populus coloniae Casinatium una cum liberis nostris), decreed the fitting erection of [this] marble statue to a worthy patron." 81

\footnotetext{
${ }^{80}$ Including with the ordo (35 statues).

${ }^{81}$ CIL X, 5200=LSA-2028: “C(ai) Pacci Felicis. / C(aio) Pạccio Felici, pat(rono), omnib(us) honorib(us) et honeri/bus pe[r]functo, filio C(ai) Pacci Felicis, patron(i) / coloniae Casin(atium), cuius inmensis (sic) bene/ficiis patria cognoscitur cumulata, cur(atori) / r(ei) p(ublicae) nost(rae), cuius provisione semper feliciter / guvernati (sic), cur(atori) et instauratori aedium / publicarum cuius opera et sollicitu/dinem inpendiisque propriis post / seriem annorum therm(a)e Noviani / nobis in usu sunt restitutae, ob his / omnibus laboribus eius quos cir/ca patriam civesque suos exibuit, / digno patrono universus / populus coloniae Casinati/um una cum liberis nostris / statuam marmoream erigen/dam digne censuimus."
} 
Although the dating of Felix's statue remains uncertain, the eloquent language of the inscription, the style of the letters, and the fact that he was a curator rei publicae of local origin point to a fourth century date. ${ }^{82}$ Felix was honoured for his leadership and benefactions, including the restoration of the city's baths. It is the dedication by the whole populus with their children, however, that makes this inscription interesting for us. An assembly of the populus could vote civic honours, but the inclusion of a reference to their children reminds us that these were not just administrative records (which they were), but political artefacts as well. The choice of words emphasised unity in a moment when dissent was a real possibility. More significantly, the inscription emphasised a commitment for the future, something that was probably more effective because of the involvement of the whole populace (including the future generation). This is also indicated by a dedication from Interamna Nahars (Tuscia et Umbria), datable to 338:

“The honey of Leucadius. To Helvidia Burrenia Modesta, granddaughter of Helvidius Burrenus Severus, of clarissimus rank, daughter of Burrenia Severa, woman of clarissimus rank, memorable in chastity, wisdom and innocence among all past [women]; on account of her service and love, the citizens of both sexes of the city of Interamna, with the funds having been collected, [set this up] to their patron after her death." $" 83$

This is a rare dedication to a non-imperial female honorand in late antique Italy. Modesta was a descendant of a senatorial family and a local patron, a status that might explain such an unique honour. The reference to a dedication by the citizens of both sexes is also of great interest here: an uncommon category of awarder, even for earlier periods. ${ }^{84}$ It is probable that funds for the honour having been collected from

\footnotetext{
${ }^{82}$ Suggested by Camodeca, 1980, 494-495; Solin, 2016, 670; EDR162991 dates it to the fourth century based on the palaeography.

${ }^{83}$ CIL XI, 4180=LSA-1635: "Laeucadii Mel. / Helvidiae Burreniae / Modestae, / nepoti Helvidi Burreni $\mathrm{Se} / \mathrm{veri}$, v(iri) c(larissimi), filiae Burreniae Se/verae, c(larissimae) f(eminae), pudicitia, sapientia, / innocentia omnibus retro / memorabili, ob meritum amo/remque eius, cives Interam/nanae civitatis utriusque / sexsus (sic) (a)ere conlato post / obitum huius / patronae."

${ }^{84}$ For earlier examples, see $C I L \mathrm{X}, 5067=E D R 151617$ and $C I L$ XI, 5711=EDR 110115 . The use of the expression "utriusque sexus" to refer to the recipients of benefactions (or rights) is more common, for example in funerary monuments: $C I L \mathrm{X}, 1507=E D R 145363$ and $C I L$ VI, 26106; see $A E$ 1894, $148=E D R 071619$ for benefactions.
} 
male and female citizens alike, the dedication would have to be made in the name of both. The phrasing of the inscription emphasises the unanimous character of the decision - as the reference to the children of the populus, in the inscription from Casinum. It is still unclear, however, whether the decision was made in a formal civic gathering extraordinarily open to women and men, or whether an acclamation in another form of popular gathering (such as in the theatre or amphitheatre) was later confirmed in an official meeting of one of the city's assemblies. ${ }^{85}$ In any case, this example confirms the image of great vitality in the forms of civic life in early fourth century Italy.

All across Italy, members of different social groups played a defining role in the working of the late antique economy of honours. As we saw above, the plebs urbana of Hispellum dedicated a statue to the coronatus Tusciae et Umbriae Caius Matrinius Aurelius in the mid-fourth century for his benefactions. In this case, Aurelius' generosity benefitted a much broader range of groups than the local plebs: as the games were part of a provincial celebration of the imperial regime, inhabitants of other cities probably also attended it, and the whole city of Hispellum gained prestige as a result. ${ }^{86}$ In Praeneste (Campania), members of a collegium dedicated a posthumous statue in the forum to Publius Aelius Apollinaris Arlenius, a benefactor who had endowed them with properties and funds. ${ }^{87}$ In this case, the language of the inscription, celebrating the deceased for having been "sought in heaven so that he might be freed from bodily prison" (caelo desideratus corporeo liberaretur) has been interpreted as indicating Arlenius' Christian beliefs. If this is correct, the statue is a striking illustration of how flexible this form of civic honour could be, incorporating a reference to the honorand's religious commitments, but also how different groups could manipulate these honours according to their interests in the most prestigious location in town. This is also brought up by another statue, dedicated by the centonarii (textile dealers) of Capua to a patron who had enjoyed a career locally as well as in Rome, probably in front of a Christian church ("[ante] sedem dei ponendam") in $367 .{ }^{88}$ The involvement of city regions or neighbourhoods (vici and

\footnotetext{
${ }^{85}$ For a useful survey of the history and epigraphy of Interamna Nahars, see Andreani and Fora, 2002; for the archaeology of the late antique city, Angelelli and Zampolini Faustini, 2006.

${ }^{86}$ CIL XI, 5283=LSA-1638.

${ }^{87}$ EphEp IX, 776=LSA-1685; see also M. G. Granino Cerere in SupplIt - Imagines, Latium Vetus 1, 646, and Liu, 2012.

${ }^{88}$ CIL X, 4724=LSA-1968; see also Chioffi, 2005, n. 200; on the centonarii as textile dealers, see more recently Liu, 2009, 57-96.
} 
regiones) in the setting up of statues has been well studied for Puteoli, where a number of regiones dedicated statues to different honorands. ${ }^{89}$ The most eloquent example is the case of the provincial governor and city patron Quintus Flavius Maesius Lollianus, who was commemorated in separate dedications by four different regions (one of which also commemorated his son) in the middle of the fourth century. ${ }^{90}$ The same behaviour is attested to in other Campanian cities like Naples, Beneventum, Nola, and Capua. ${ }^{91}$ In total, groups like the populus and collegia were responsible for 115 out of the 201 dedications made by local awarders in all of Italy (c. $57 \%)$.

The participation of non-elite groups in the late antique economy of honours was also important because it offered the possibility of political dissent as much as support in civic life. An earlier example (probably from the later part of the first century AD) from Ausugum, in Venetia et Histria, illuminates some of the sociopolitical dynamics that could be at play in the award of such distinctions. ${ }^{92}$ The inscription records the case of a local notable who, after having provided gladiatorial games and helped the city at a time of scarcity, was rewarded by the plebs with a gilded statue paid for by a public collection; the members of the local council, however, did not accept the honour, and exiled the unnamed benefactor. In this case, the plebs was moved by the generosity of its benefactor to collect funds and set up an extraordinary monument - an initiative that affected the balance of the local economy of honours, causing the other members of the nobility to react and punish their peer. In this case, political discord divided members of the same elite who competed for prestige, and the plebs played a structural role in this process. There is no similar example that I know of for Late Antiquity, but the possibility of disagreement (or the fear thereof) is raised by a fourth century dedication from Canusium:

\footnotetext{
${ }^{89}$ Camodeca, 1977.

${ }^{90} A E$ 1977, 198=LSA-47 (regio arae Lucullianae); CIL X, 1695=LSA-332 (regio Portae Triumphalis); EphEp VIII, 365=LSA-1909 (regio clivi vitriari(i) sive vici turari(i)). CIL X, 1696=LSA-42 and CIL X, $1697=L S A-335$, respectively to Lollianus and his son, were set up by the Decatrenses, identified by Camodeca, 1977, 66-70 as inhabitants of the regio Decatriae. For other statues dedicated by regions of Puteoli, see $C I L \mathrm{X}, 1794=L S A-1916 ; A E$ 1983, 197=LSA-42; CIL X, 1700=LSA-1910.

${ }^{91}$ For Naples: $C I L$ X, 1492=LSA-1901; CIL X, 1680=LSA-1908. Beneventum: CIL IX, 1569=LSA1730; Nola: CIL X, 1251=LSA-1869; CIL X, 1255=LSA-1871; CIL X, 1256=LSA-1872; Capua: $A E$ 1972, 75a-b=LSA-1941; AE 1972, 76=LSA-1936; CIL X, 3857=LSA-1940.

${ }^{92} C I L$ V , 5049=EDR137928; A. Buonopane dates it according to the palaeography (SupplIt 12 (1994), n. 2. See also the studies of Wistrand, 1981, and Martin, 1996.
} 
"[Statue of] Athenasius. To Lucius Annius Rufus, son of Lucius, from the Oufentina tribe, of egregius rank in every action of his life, patron of the colony; having the people requested an equestrian [statue] to the judges, he [being] satisfied with the honour of a standing statue, returned their favour." 93

The offer of an equestrian statue was an unusual honour in Late Antiquity, especially to a local notable. ${ }^{94}$ The honorand's display of moderation can be seen, in this sense, a case of political sensitivity as much as of genuine humbleness. For the imperial officers (the judges) who received the request, and the members of the elite of Canosa, however, the degree of popular support for Rufus was clear. The recording of his recusatio in the monument made sure that popular will was registered publicly, whilst also documenting his respect for his colleagues. The case of Rufus also raises the issue of the choices made for the bestowal of honours. As a member of Canusium's traditional elite, Rufus and his descendants would have seen his portrait in the company of other men (and possibly women too) of similar social background. An equestrian or a gilded portrait was a form of setting one apart from this population of statues, something that required a carefully built consensus among the different factions within both the elite and the populus (and the plebs). Showing commitment for social and political harmony could be just as important as boasting of unique honours, especially at a time of great social changes. When strolling through the streets of their cities, curiales would also see, in increasing numbers, monuments celebrating honorands that indicated a profound change in the economy of local honours.

\section{The new faces of power}

Every honour bestowed by a civic community was the product of a careful political decision. The 408 statues (and fragments), inscribed bases, and textual references documented for Italy belong to 138 different cities, which means that on average each civic community was responsible for 2.95 statues over 270 years. In the South of Italy

\footnotetext{
${ }^{93}$ CIL IX, 339=LSA-1696: “Athenasi. / L(ucio) Annio L(uci) f(ilio) Ouf(entina) / Rufo, e(gregio) v(iro) in omni / actu vitae suae, / patr(ono) col(oniae), huic popul(us) / aput (sic) iudices eques/trem postulasset, / contentus honorem (sic) / statuae pedestris / voluntati eorum gra/tiam retulit." See Christol and Magioncalda, 1996, 28-30 for the date.

94 The only example recorded in $L S A$ is Tantillo and Bigi, 2010, n. 39=LSA-2195. The database records nine equestrian statues for emperors (including Rome and Constantinople) and four for imperial officials.
} 
and Sicily, 81 cities erected 292 such monuments (3.6 per city on average), and in the North and Sardinia 57 cities were responsible for 116 statues ( 2 statues per city). Averages are misleading: Aquileia in the North accounts for 25 statues, whereas Beneventum and Puteoli in the South account for 26 and 33, respectively. It is clear that the bestowal of a civic honour was an exceptional moment in civic life, as well as a significant decision in local politics. Symmachus' letter to his father is a powerful reminder of how such initiatives could entangle potential benefactors and patrons in a web of obligations. ${ }^{95}$ At a time when the overall number of dedications declined, different groups competed to assert their priorities in this process. The evidence available allows us to identify the general trends that informed the production of civic honours. This is clearer in the case of statue dedications, particularly for the better documented case of the cities of Campania. Table 4 presents the chronological distribution of honorands awarded with statues by local Campanian communities and their officials, the same groups considered in Table 3 - it excludes dedications by governors, for example.

\begin{tabular}{|c|c|c|c|c|c|c|c|}
\hline Honorand & $\mathbf{2 8 4 - 3 1 2}$ & $\mathbf{3 1 2 - 3 3 7}$ & $\mathbf{3 3 7 - 3 7 9}$ & $\mathbf{3 7 9 - 4 0 8}$ & $\mathbf{4 0 8 - 4 5 5}$ & Uncertain & Total \\
\hline Emperors & 13 & 7 & 3 & 0 & 0 & 1 & 24 \\
\hline $\begin{array}{c}\text { Imperial } \\
\text { officials }\end{array}$ & 1 & 0 & 1 & 0 & 3 & 2 & 7 \\
\hline Senators & 5 & 1 & 2 & 3 & 0 & 5 & 16 \\
\hline Governors & 0 & 5 & 11 & 7 & 4 & 6 & 33 \\
\hline $\begin{array}{c}\text { Local } \\
\text { notables }\end{array}$ & 5 & 3 & 4 & 1 & 0 & 13 & 26 \\
\hline Total & 24 & 16 & 21 & 11 & 7 & 27 & 106 \\
\hline
\end{tabular}

Table 4: Distribution of statue dedications, honorands per period (Campania) ${ }^{96}$

Between the end of the third and the beginning of the fourth century, local awarders were deeply committed to the celebration of imperial power. Emperors and members of their families (especially Helena, as mother of Constantine) were honoured with statues, in a variety of circumstances. ${ }^{97}$ In Lavinium, for example, the curator Laurentium Lavinatium, an official probably associated with the general area of the city and the status of the Laurentes Lavinates, dedicated statues to three different

\footnotetext{
${ }^{95}$ Ep. 1.3.3, mentioned above.

${ }^{96}$ Numbers do not include honorands whose identity cannot be identified and unstated dedications (i.e., statues whose inscriptions do not record an honorand).

${ }^{97}$ CIL IX, 2446=LSA-1751; CIL X, 1483=LSA-1875; CIL X, 1484=LSA-1876.
} 
emperors; the local ordo soon followed his example. ${ }^{98}$ Such a flurry of imperial dedications can be seen all over the Mediterranean, and it can be attributed to the increased role played by the central government in this period, especially the reorganisation of the provincial system.

It is worth asking whether imperial dedications can be legitimately considered civic honours, since they refer to powerful and distant rulers who only exceptionally had a personal link with municipal life. Furthermore, the dedicatory inscriptions make use of titles like pius, felix, and invictus, which were not directly connected to the concrete circumstances of local communities. Not all local awarders were involved in these dedications, either: popular assemblies, city regions, and collegia did not celebrate emperors with such monuments. These were set up instead by the community as a whole (identified as Res Publica or colonia), by the ordo, or by curatores Rei Publicae. Civic elites appear therefore as more inclined to behave in ways that were similar to that of provincial governors and other imperial officials, usually more concerned with their leaders. At the same time, imperial images dominated the landscape of most cities around the Mediterranean. The presence of an imperial statue enhanced the importance of similar monuments celebrating other honorands, thus playing an important role in the local economy of honour. Besides, imperial dedications are a clear indication of the existence of functioning civic institutions, and in this context it is more surprising to note that only three statues survive from the period after the death of Constantine: a posthumous dedication to the same emperor, as well as one to Julian as Caesar and one as Augustus. ${ }^{99}$

From the end of Constantine's reign (337) onwards, Campanian awarders almost exclusively celebrated members of the local elite, Roman senators, and provincial governors, a shift that reveals where their political priorities lay. They were more concerned with getting things done than with celebrating distant rulers. Following the administrative reforms implemented by Diocletian, governors became the most powerful imperial agents in constant contact with cities across the empire. They became essential agents in construction works, the administration of justice, and

\footnotetext{
${ }^{98}$ CIL XIV, 2074=LSA-1669 (the name of the emperor is lost), CIL XIV, 2075=LSA-1670 (to Constantius I), and CIL XIV, 2076=LSA-1672 (to Galerius), all dedicated by Iunius Priscilianus Maximus, curator. EphEp IX, 592=LSA-1677 was dedicated by the ordo, probably to Constantine I. For the office of curator and the Laurentes Lavinates, see Cooley, 2000B, 179-180. ${ }^{99} A E$ 2005, 421=LSA-1927 (deified Constantine); CIL IX, 1561=LSA-1724 (Julian Caesar); CIL XIV, 2914=LSA-1682 (Julian Augustus).
} 
the collection of taxes. ${ }^{100}$ As a result, they occupy a prominent place in the epigraphy of Late Antiquity, either as commissioners of works or as recipients of distinctions. ${ }^{101}$ Campanian awarders used civic honours as a form of stressing their links with governors, be it as a reward for benefactions and favours received, or in the hope of future advantages. Many of these honours identified governors as patrons of the local community, illustrating how personal relations and official positions could be combined to the advantage of all parties involved. A good example is a dedication from Puteoli, datable to 409:

"To Pontius Proserius Paulinus iunior, of clarissimus rank, governor of Campania, patron by descent, provider to the city, restorer of public works, irreproachable judge. For the merits of his father and his own, the most distinguished council and the most honest people of Puteoli set up this statue." 102

The monument was not presented as a response to a specific benefaction. Although praising Paulinus' performance as a governor, the inscription identifies him as patron by descent, and the dedication is explicitly credited to his and his father's merits. François Chausson showed that family patronage was a common feature in dedications in the cities of Italy and North Africa. ${ }^{103}$ As the case of Paulinus suggests, these references attest to the successful strategies of local communities and potential families of patrons, celebrating their enduring links. An inscription from Capua, to the same man, emphasises this point:

"To Pontius Proserius Paulinus, of clarissimus rank, governor of Campania, patron by descent; the councilors of Capua, always yielding to their restorer and even to his descendants, in due clientship, set up this statue." 104

\footnotetext{
${ }^{100}$ Slootjes, 2006, offers a useful survey. On the functions of governors, see Roueché, 1998. For the importance of governors in late antique Italy, see Cecconi, 1994.

${ }^{101}$ The most complete treatment remains Horster, 1998, updated in Horster, 2016.

${ }^{102}$ CIL X, 1702=LSA-339: "Pontio Proserio / Paulino iuniori, v(iro) c(larissimo), / cons(ulari)

Camp(aniae), / ab origine patrono, / provisori civitatis, / restauratori operum / publicorum, / iudici integerrimo, / ob merita patris ac sua / ordo splendidissimus / et honestissimus/ populus Puteolanus / statuam conlocabit ( sic)."

${ }^{103}$ See, on family patronage in this period, Chausson, 2004.

${ }^{104} A E$ 1972, 143=LSA-1934: "Pontio Proserio Paulino, / v(iro) c(larissimo), cons(ulari) Camp(aniae), / [p]atrono originali, / restitutori suo / splendidus ordo Cap(uensis) / semper obsecundante / etiam eius posteris / debita clientela / statuam conlocavit." Paulinus was also honoured with a statue in Formiae: CIL X, 6088=LSA-2045, badly damaged.
} 
The number of honours awarded to governors rose in the same period that the dedication of statues to emperors declined, as civic groups re-oriented their political allegiances. Most governors of Campania were senators from Rome (or with strong links with the capital), a social group that had traditionally occupied an important role in the political life of the region, as patrons and benefactors. Quintus Flavius Maesius Lollianus, for example, enjoyed a successful career in the reigns of Constantine and his successors, governing Campania at some point between 334 and 342. As we saw above, his close links with Puteoli led to his celebration by different regions in the city after the end of his term in office. ${ }^{105}$ Unsurprisingly, his son Lollianus iunior was also celebrated with a statue in the same city, as a patron. ${ }^{106}$

Members of the municipal elites continued to occupy an important place in the economy of civic honours, as can be seen in the case of Campania. Here, curiales and curatores Rei Publicae were honoured as patrons, for their benefactions, or for the potential they offered to the local community. A remarkable example is offered by a series of statues awarded to different members of the family of the Tannonii, from Puteoli, recently re-discussed by Giuseppe Camodeca. ${ }^{107}$ At some point between 360 and 380, the most important member of the family, Tannonius Chrysantius, was honoured by the populus as a patron, and praised as a man "of a splendid and famous lineage, provider of the citizens, unblemished protector, superior in glory". ${ }^{108}$ The date is suggested by another inscribed statue base, in which he is mentioned as assisting the governor Virius Audentius Aemilianus, active either in 375-376 or 377378. ${ }^{109}$ Tannonius was honoured again in a later statue, dedicated with a verse inscription, also set up by the ordo and the populus. ${ }^{110}$ Tannonius' wife, Vibia Luxuria, was also honoured with a statue in the city. ${ }^{111}$

\footnotetext{
${ }^{105} C I L \mathrm{X}, 1696=L S A-43, A E$ 1977, 198 $=L S A-47, C I L \mathrm{X}, 1695=L S A-332$, and EphEp VIII, 365=LSA1909. He was also honoured at Suessa: $C I L \mathrm{X}, 4752=L S A-1970$. See, on Lollianus, PLRE I, Lollianus, 5.

${ }^{106}$ CIL X, 1697=LSA-335. See, on these bases, Camodeca, 1980-1981.

107 Camodeca, 2014. See also Camodeca, 1980-1981.

108 AE 1976, 141=LSA-45: "Tannoni Crhysanti (sic), v(iri) p(erfectissimi), / patroni. / Magnificae adque praeclar(a)e stirpis viro, / provisori civium, defensori integro, / gloriam praepollenti, secutus ordinis / splendidissimi exemplo, / devotissimus populus ornamenta / statuae in aevum mansura / supplex caelebri (sic) loco erigenda decrevit." It is not clear whether the inscription refers to another statue dedicated by the ordo or to the role played by the ordo in this same dedication.

${ }^{109}$ CIL X, 3714=LSA-1921; see Camodeca, 2014, 122, for the date.

${ }^{110}$ CIL X, 1813=LSA-1911, cited above.

${ }^{111}$ CIL X, 3107=LSA-1919; see Camodeca, 1980-1981, 121 for the identification.
} 
Tannonius was later appointed governor of Byzacena and promoted to the rank of clarissimus, probably between 380 and 390. This information is only recorded on the base of a statue set up by the ordo and the populus of Puteoli to his son, also called Tannonius Chrysantius, identified as patron since his birth (ab origine nato patrono). ${ }^{112}$ The political and social advancement of the elder Tannonius confirmed the hopes of the people of Puteoli, who would still honour another member of the family, a Tannonius Boionius Chrysantius (also a patron), possibly the grandson of the former governor of Byzacena. ${ }^{113}$ As the statues dedicated to the Tannonii show, the ambitions and political networks of powerful local families were important assets that deserved to be nurtured as much as advertised. The case of this successful Puteolan family is exceptional not only because of the insight it provides into the history of a family of notables, but also because it can be dated with some degree of precision. Dedications to members of local elites are much harder to date than those made to governors and senators, whose names and careers can more often be confronted with other types of evidence. ${ }^{114}$ As a result, half of all statues awarded to members of city elites in Campania cannot be properly dated (Table 4 above). It is probable, however, that the development suggested by the securely datable dedications, with a stable number for most of the fourth century and a sharp decline towards its end, is correct: it fits well with the broader trend of decline in the number of dedications by local awarders and the transformation of the classical economy of honours (as will be shown in the Conclusion).

The case of Campania puts developments in other parts of Italy in sharper focus. This is important not only because the amount of evidence available for each province is much smaller, but also because in most cases no new dedications were made after the reign of Julian. In other words, the late antique statue habit in Italy was exceptionally vibrant for a few decades in the fourth century, but it did not last long. Here too we can see a few general trends. Throughout Italy, local communities were deeply involved in the celebration of imperial power during the Tetrarchic and the Constantinian periods. Different emperors were celebrated with statues set up by cities, councils, and officials. Licinius, for example, was celebrated in Volcei

\footnotetext{
$112 A E$ 2014, 324=LSA-1912; see Camodeca, 2014 for discussion.

${ }^{113}$ CIL X, 1815=LSA-1914.

${ }^{114}$ In spite of considerable gaps in our knowledge of the fasti of the governors of Italian provinces: see Cecconi, 1994, 209-224.
} 
(Lucania et Brittii), Pola, and Parentium (both in Venetia et Histria). ${ }^{115}$ In spite of this brief surge, the number of imperial dedications declined in the following decades, and imperial dedications had become a rare occasion by the middle of the fourth century, just as in Campania, as seen above. ${ }^{116}$ Perhaps the most striking development in the economy of honours of this period was the fact that civic groups soon stopped awarding statues to members of the local elite. Even in the case of Tuscia et Umbria, where civic awarders remained particularly active, their political priorities moved away from local leaders. ${ }^{117}$ This does not mean that local notables were excluded from civic honours. In the province of Lucania et Bruttii, for example, where no statue was dedicated to a municipal leader in Late Antiquity, the ordo and the populus of Paestum were very active in co-opting patrons and producing tabulae patronatus in the first half of the fourth century. ${ }^{118}$ In Apulia et Calabria, Flavius Sucessus was coopted as patron of Genusia as late as 395 , at a time when statues were not being dedicated to local men or women in the area anymore. ${ }^{119}$

Perhaps more revealingly, the decline in the number of dedications to emperors and local notables took place at a time when local councils and assemblies continued to award statues to senatorial patrons and imperial officials. Although the numbers here are much smaller than in Campania, the overall trend is the same, probably for the same reasons. ${ }^{120}$ Dedications to senators (be it as governors or not) took place not only in the awarding city, but also in the houses of these aristocrats in Rome, usually by provincial councils. ${ }^{121}$ A good example of this practice is the statue dedicated by the inhabitants of Forum Novum, datable to 400:

\footnotetext{
${ }^{115}$ Respectively, $C I L \mathrm{X}, 406=L S A-1813 ; C I L \mathrm{~V}, 31=L S A-1209 ;$ and $C I L \mathrm{~V}, 330=L S A-1213$.

116 The latest dedications to emperors made by local communities in Italy are CIL V, 3113=LSA-1237 (Valens), $C I L \mathrm{~V}, 3114=L S A-1238$ (Gratian), both from Vicetia (Venetia et Histria), and CIL IX, $661=L S A-1704$ (Valentinian), from Ausculum (Apulia et Calabria), in the 370s.

${ }^{117}$ A possible exception is the fragmentary base of a statue dedicated to a coronatus Tusciae et Umbriae from Carsulae ( $A E$ 2014, 408=LSA-2859) that might be dated to the second half of the fourth century according to its palaeography: see $E D R 135070$.

${ }_{118}$ CIL X, 476=EDR122208 (337); CIL X, 478=EDR135326 (344); CIL X, 477=EDR157430 (347); $A E$ 1990, $211=E D R 081748$ (347). Awarders from Lucania et Brittii dedicated eight statues to emperors, six to governors, and two whose subject was left unstated.

${ }^{119}$ CIL IX, 259=EDR163418 for the tabula. For the late statues, see CIL IX, 339=LSA-1696; AE 1945,81=LSA-1699; CIL IX, 688=LSA-1712; and CIL IX, 1128=LSA-1722.

120 This is not the space for a more detailed study of regional variations, which would be necessary.

${ }^{121} C I L$ VI, $1751=L S A-272$ (by Venetia et Histria); CIL VI, 1702=31904=LSA-1406 (by Tuscia et Umbria); $C I L$ VI, $31961=L S A-1536$ (by Sicilia); and $C I L$ VI, 1706=LSA-1413 (by the city of Forum Novum). Other provinces also dedicated in Rome: CIL VI, 1729=LSA-323 (Hispaniae); CIL VI, $1722=L S A-1425$ (Numidia); CIL VI, 1736=LSA-1439 (Africa). The practice of dedicating statues in the Roman residences of senators and aristocrats was not new: Eck, 1997.
} 
"(Statue) of Gregarius, of clarissimus rank. To Cheionius Contucius, of clarissimus rank, an illustration of his stock both through his outstanding deeds and rare example of old-fashioned sanctity, for whose support the entire province of Picenum et Flaminia is grateful for its growth and restoration, because with him judging like an ancestral parent, individual cities were delighted to be brought back to their pristine form. The Foronovani, anticipating the wishes of the entire province, have set up a statue for lasting remembrance and in eternal memory."122

Ammianus Marcellinus commented on senatorial eagerness for statue monuments, criticising them for desiring a form of honour that surpassed their achievements and qualities. ${ }^{123}$ It is not surprising, therefore, that imperial legislators were concerned about governors extorting such honours from their subjects, and tried to regulate this practice. A law issued in the late fourth century had already attempted to regulate the bestowal of these honours, establishing that bronze, silver, and marble statues could only be awarded to governors after imperial approval. ${ }^{124}$ The law was addressed to Flavius Mallius Theodorus, praetorian prefect of Italy, and it is unlikely that the abuse of the classical forms of honorific distinction had not caught the attention of imperial legislators. This is also suggested by a law of Theodosius II and Valentinian III, which although addressed to the East, highlights developments that were also taking place in the West:

"It is both fitting that prizes for virtue should be granted to those deserving them, and that the honours of some should not lead to damage to others. Therefore, whenever a statue is offered by any collegium or office in this most sacred city [Constantinople] or in the provinces to one of our judges or to someone else, we do not allow the expenses to be collected from apportionment, but from him for whom the honour was requested, and with whose own funds we order the statue to be dedicated."125

\footnotetext{
${ }^{122}$ CIL VI, 1706=LSA-1413: “Gregarii, v(iri) c(larissimi). / Cheionio Contucio, v(iro) c(larissimo), / ob egregia facta et ra/rum veteris sanctitatis / exemplar, inlustraturi (sic) / prosapiae suae, cuius ope / auctam instauratamq(ue) / tota se Piceni et Flami/niae provincia gratu/latur, quo iudicante qua/si quodam parentem / prim(a)evo singulae ci/vitates in pristinam faci/em revocatas esse 1(a)etan/tur Foronovani / desidideria totius / provinciae prae/cedentes statu/am ad vivacem recor/dationem et sempiterna(m) / memoriam posuerunt."

${ }^{123}$ Ammianus Marcellinus, 14.6.8; on late Roman senators and statues, see Weisweiler, 2012.

${ }^{124} C J$ 1.24.1 (from 398), addressed to Theodorus (PLRE I, Theodorus 27).

${ }^{125}$ CJ 1.24.4: "Et virtutum praemia tribui merentibus convenit et aliorum honores aliis damnorum occasionem fieri non oportet. Idcirco quotiens vel iudicibus nostris vel cuilibet alii statua fuerit a
} 
As the example of Italian cities discussed in this article shows, this pressure from above was a real issue in the evolution of the late Roman statue habit. Ultimately, senatorial hunger for statues and other signs of distinction was not motivated by the same expectations and ambitions as those that animated the bestowal of signs of civic honour. ${ }^{126}$ That members of the senatorial elite would dominate our record for honorific statues is a development that had grave implications for the classical economy of honours, and this is what we must consider in the Conclusion.

\section{Conclusion}

In $\mathrm{AD} 408$, the populus of Interamna Lirenas (Campania) gathered to vote what had by that time become an unusual honour to Marcus Sentius Redemptus, a member of a leading local family:

"To Marcus Sentius Redemptus, outstanding in industry and wisdom, a praiseworthy man, leading citizen of our city, who fulfilled all the offices [of the city] and the offices of the council, who by birth came to be [our] patron, who his people by his benevolence rendered his people free from the tax of gold and silver, who restored the summer baths, that had collapsed into squalour and ruin, at his own expense [and] to the highest standard, of whom so many good deeds towards us were accumulated, [and] to whose eternal fame the entire people of Interamna decided that a statue should be erected."127

As late as the first decades of the fifth century, groups like the plebs and the populus still assembled in different cities of Italy to bestow honours on members of the local elite, and the statue of Redemptus is an eloquent reminder of this fact. Like men (and

quocumque collegio seu officio vel in hac sacratissima civitate vel in provinciis postulata, nequaquam ex discriptione sumptus colligi patimur, sed eius, cuius ad honorem petitur, expensis propriis statuam collocari praecipimus." The law was addressed to Nomus, Magister Officiorum of the East (PLRE II, Nomus 1).

126 This is explored in Machado with Lenaghan, 2016.

${ }^{127}$ CIL X, 5349=LSA-2030: "Industriae ac sapientiae praeclaro, / M(arco) Sentio Redempto, v(iro) 1(audibili), primario civitatis / nostrae, omnibus honoribus et honoribus cu/riae suae perfuncto, ex origine patronatus / venientem (sic), que (sic) populum suum pro sua be/nivolentia ab indictione auri argentiq(ue) pop[u]/lum suum liberum reddidit, termas extivas (sic) / in sordentibus ac ruina conlabsas ex prop[rio] / ad summamm (sic) manum revocavit, cuius tantis / be[ne]ficiis circa nos comulatis, cuius ad perpetuam fa/mam statuam eidem erigendam universus / populus Interamnatium censuerunt." Redemptus was a relative of Marcus Sentius Crispinus, honoured in CIL X, 5348=LSA-2029, an undated inscription. 
occasionally women) of previous generations, Redemptus was celebrated for his services and generosity towards his fellow citizens. However, in spite of its dynamism, the involvement of local assemblies and officials in the bestowal of civic honours declined in the course of the fourth century, and the statue dedicated by the people of Interamna was by then a very unusual happening in the life of Italian cities. It would be impossible to chart this process with adequate precision: the number of statues dedicated is too small and inconsistent regionally; statistically insignificant, the survival rate of the evidence is too low; and a large number of dedications cannot be properly dated. And yet, it is clear that the number of dedications by local awarders declined even in provinces where the statue habit was stronger. In Flaminia et Picenum, for example, seven out of the eight datable dedications were carried out in the period between 280 and 337. In Tuscia et Umbria, 13 out of the 20 datable dedications made by local awarders belong to this same period, and the remaining seven to 337-379. Even in the exceptionally rich case of Campania, more than 50\% of these dedications (43 out of 83 ) are datable to the period before the death of Constantine. The only exception for this trend is the province of Samnium, where most of the datable local dedications (11 out of 24) took place in the central decades of the fourth century, when the province was created possibly as a response to an earthquake. ${ }^{128}$ This was an exceptional case that soon fell into the same pattern as the others.

Local awarders did not stop dedicating statues at once: as in the case of Redemptus, there are very late examples from different provinces, the latest being a statue voted by the ordo and the populus of Venafrum (Samnium) to a governor of spectabilis rank, datable to the Ostrogothic period. ${ }^{129}$ These were exceptional dedications, however, few and far between, all of them originating from the South of the peninsula. By all standards, the late antique statue habit was already dead by the last decades of the fourth century. ${ }^{130}$ The disengagement of local communities, and especially of its non-elite members, in the dedication of statues indicates a radical development in the classical economy of civic honours. As we saw in Section 3,

\footnotetext{
${ }^{128}$ See, for the much debated creation of the province and its institutional history, Clemente, 1965; Camodeca, 1971; Iasiello, 2007, 39-50.

${ }^{129}$ CIL X, 4859=LSA-328. The earliest evidence for governors of spectabilis rank that can be securely dated is Cassiodorus' Variae, see Chastagnol, 1963, 373-374. See, for further examples of late dedications, CIL XIV, $2165=L S A-324$ (437); AE 1894, 89=LSA-327 (408-331); AE 1957, 43=LSA-1694 (400-440).

${ }^{130}$ A process discussed in Machado, 2010.
} 
governors and other officials coveting honorific statues could put considerable pressure on those living or working under their authority - members of their staff being a prime target. The extortion of honours by government officials was not something new, and emperors like Augustus had tried to curb it by imposing limits on the bestowal of honours in the provinces. ${ }^{131}$ In the context of the decreasing number of honours bestowed by local communities, however, the law of Theodosius II and Valentinian III mentioned earlier suggests that by the early fifth century the classical economy of honours had been thoroughly subverted: distinction was sought from above (the honorand), rather than offered from below (the awarders).

Besides statues, other forms of civic honour were bestowed in the late antique period, and not all led to material representations in marble or bronze. The disappearance of three-dimensional forms of representation in favour of twodimensional ones, like painted portraits, is a development that is only now attracting proper attention from scholars. ${ }^{132}$ Local elites still celebrated their power in public and not so public spaces, like catacombs and churches. Jean-Pierre Caillet's studies of mosaic inscriptions and portraits in the churches of Italy show the continued importance of classical practices, for the same reasons of self-display, but in a radically new context. ${ }^{133}$ As they gained greater currency, such forms of celebration of power allowed members of the municipal elites, senatorial patrons and emperors to promote their image as patrons and pious members of the Christian community, in the company (and under the leadership) of a new source of authority, the bishop and his saints. ${ }^{134}$ Their power, as Caillet observed, was a divine concession. ${ }^{135}$ Although at different times, these developments were also taking place in other parts of the empire. ${ }^{136}$

The decline of the statue habit and the greater currency of painted portraits as a form of displaying power were not the result of cultural or religious changes only. As the evidence from Italian cities discussed above suggests, these developments were part of a broader change in civic life and urban society. Italian cities were incomparably active in bestowing civic honours for the greater part of the fourth

\footnotetext{
${ }^{131}$ Dio Cassius, 56.25.6 for Augustus; Lendon, 1997, 196 for other examples.

${ }^{132}$ Liverani, 2016, refers to it as "The sunset of 3-D". See also Bisconti, 2015.

133 Caillet, 1993 and 2011.

${ }^{134}$ For a good discussion of these issues, see Sotinel, 2005, for Aquileia.

135 "[U]n pouvoir de concession divine", as in the subtitle of Caillet, 2011.

${ }^{136}$ Elsner, 1998, 221-235 raises the broader issues; for a study of church decoration and community life in the late antique Mediterranean, see Yasin, 2009; my discussion is indebted to Liverani, 2018.
} 
century. They inherited and adapted a classical system that allowed different members of the community to express their traditional values and the changing hierarchies of power. Their involvement in this series of exchanges declined towards the end of the century, however, as new sources of legitimacy became more relevant to the powerful. Whereas classical honours like statues and civic titles were awarded by local communities, paintings, mosaics, and church inscriptions did not require the same social obligations that weighed traditional elites down. They recorded an offering that might have benefitted the whole community, but that was ultimately aimed at God.

\section{Bibliography}

Alföldy, G., 1979 "Bildprogramme in den römischen Städten des Conventus Tarraconensis - Das Zeugnis der Statuenpostamente", in Revista de la Universidad Complutense, 118, 177-275.

Ando, C. 2000 Imperial Ideology and Provincial Loyalty in the Roman Empire, Berkeley.

Andreani, C. and Fora, M. 2002 "Interamna Nahars", in Supplementa Italica, n.s., 19, $11-128$.

Angelelli, C. and Zampolini Faustini, S. 2006. "Interamna Nahars (Terni) tra antichità e medioevo: persistenze e trasformazioni alla luce delle più recenti ricerche archeologiche", in M. Ghilardi, C. Goddard, and P. Porena (dirs.), Les cites de l'Italie tardo-antique (IVe-Vie siècle), Rome, 217-233.

Augenti, A. (dir.) 2006, Le città italiane tra la tarda antichità e l'alto medioevo, Florence.

Ausbüttel, F. 1988 Die Verwaltung der Städte und Provinzen im spätantiken Italien, Frankfurt am Main.

Bisconti, F. 2015 "I volti degli aristocratici nella tarda antichità. Fisionomie e ritratti nelle catacombe romane e napoletane", in C. Ebanista and M. Rotili (dirs.), Aristocrazie e società fra transizione romano-germanica e alto medioevo, Cimitile, 27-46.

Buonocore, M. 1992 “C. Herennius Lupercus patronus Larinatium”, in Tyche, 7, 1925. 
Caillet, J.-P. 1993 L'évergétisme monumental chrétien en Italie et à ses marges, Rome.

Caillet, J.-P. 2011 "L'image du dédicant dans l'édifice cultuel (IVe-VIIe s.): aux origines de la visualisation d'un pouvoir de concession divine", in AnTard, 149-169.

Cameron, A. 1976 Circus Factions: Blues and Greens at Rome and Byzantium, Oxford.

Camodeca, G. 1971 "Fabius Maximus e la creazione della provincial del Samnium", Atti dell'Accademia di Scienze Morali e Politiche di Napoli, 82, 249-264.

Camodeca, G. 1977 "L'ordinamento in regiones e vici di Puteoli", in Puteoli 1, 62-98.

Camodeca, G. 1980 "Ricerche sui curatores rei publicae”, in ANRW, II.13, 453-534.

Camodeca, G. 1980-1981 "Ricerche su Puteoli tardoromana (fine III-IV secolo)", in Puteoli, 4-5, 59-128.

Camodeca, G. 2008A I ceti dirigenti di rango senatorio, equestre e decurionale della Campania romana, vol. 1, Naples.

Camodeca, G. 2008B "I curatores rei publicae in Italia: note di aggiornamento", in C. Berrendonner, M. Cébeillac-Gervasoni, and L. Lamoine (dirs.), Le quotidien municipal dans l'Occident romain, Clermont-Ferrand, 507-521.

Camodeca, G. 2010 "Le città della Campania nella documentazione epigrafica pubblica del tardo III-IV secolo", in G. Volpe and R. Giuliani (dirs.), Paesaggi e insediamenti urbani in Italia meridionale fra tardoantico e altomedioevo, Bari, 283294.

Camodeca, G. 2013 “Senatori beneventani da Silla alla tetrarchia”, in P. Caruso (dir.), Antiqua Beneventana, Benevento, 233-262.

Camodeca, G. 2014 "Un nuovo consularis Byzacenae di tardo IV secolo e i Tannonii di Puteoli", in Arctos, 48, 121-135.

Carlà, F. 2009 L'oro nella tarda antichità: aspetti economici e sociali, Turin.

Carlá, F. and Gori, M. (eds) 2014 Gift giving and the 'embedded economy' in the ancient world, Heidelberg.

Cecconi, G. A. 1994 Governo imperiale e élites dirigenti dell'Italia tardoantica, Como.

Cecconi, G. A. 2006 "Honorati, possessores, curiales: competenze istituzionali e gerarchie di rango nella città tardoantica”, in R. Lizzi Testa (dir.), Le trasformazioni delle élites in età tardoantica, Rome, 41-64. 
Cecconi, G. A. 2012 "Il rescritto di Spello: prospettive recenti", in G. Bonamente, N. Lenski, and R. Lizzi Testa (dirs.), Costantino prima e dopo Costantino, Bari, 273290.

Chaniotis, A. 2009 "Acclamations as a form of religious communications", in H. Cancik and J. Rüpke (dirs.), Die Religion des Imperium Romanum, Tübingen, 199218.

Chastagnol, A. 1963 "L'administration du Diocèse Italien au Bas-Empire”, Historia, $12,348-379$.

Chausson, F. 2004, "Les patronats familiaux en Afrique et en Italie aux IVe-Ve siècles: un dossier épigraphique", in Atti dell'Accademia Nazionale dei Lincei. Rendiconti di scienze morali, storiche e filologiche, s. 9, v. 15, 71-120.

Chioffi, L. 2005 Museo Provinciale Campano di Capua. La Raccolta Epigrafica, vol. 1, Capua.

Christol, M. and Magioncalda, A. 1996 "Continuités dans la vie municipale à l'époque tardive d'après l'épigraphie de Canusium (Canosa, Italie)", in C. Lepelley (ed), La fin de la cité antique et le début de la cité médiévale, Bari, 25-42.

Clemente, G. 1965 "Due note sulla storia delle diocese italiciane nel IV secolo: 1. La creazione del Samnium e la datazione della Historia Augusta", Athenaeum, 53, 355368 .

Cooley, A. (dir.) 2000A The Epigraphic Landscape of Roman Italy, London.

Cooley, A. 2000B "Politics and Religion in the Ager Laurens", in A. Cooley (dir.), The Epigraphic Landscape of Roman Italy, London, 173-191.

Dagron, G. 2011 L'hippodrome de Constantinople, Paris.

De Maria, S. 2017 'Celeberrimi loci'. Studi sulle strategie della celebrazione nel mondo romano, Bologna.

Delogu, P. and Gasparri, S. (eds) 2010 Le trasformazioni del V secolo. L'Italia, I barbari e l'Occidente romano, Turnhout.

Dillon, J. 2012 The Justice of Constantine: law, communication, and control, Ann Arbor.

Domingo Gygax, M. 2016 Benefaction and Rewards in the Ancient Greek City: the origins of evergetism, Cambridge.

Dossey, L. 2010 Peasant and Empire in Christian North Africa, Berkeley. 
Eck, W. 1997 "Rome and the outside world: senatorial families and the world they lived in", in B. Rawson and P. Weaver (dirs.), The Roman Family in Italy, Oxford, 73-99.

Elsner, J. 1998 Imperial Rome and Christian Triumph, Oxford.

Fagan, G. 1999 Bathing in Public in the Roman World, Ann Arbor.

Freu, C. 2007 Les figures du pauvre dans les sources italiennes de l'Antiquité tardive, Paris.

Ghilardi, M.; Goddard, C. and Porena, P. (dirs.) 2006 Les cites de l'Italie tardoantique (IVe-Vie siècle), Rome.

Goddard, C. 2002 "Les formes festives de l'allégeance au Prince en Italie central, sous le régne de Constantin: un suicide religieux?", in MÉFRA, 114.2, 1025-1088.

Gregori, G. 2008 “Huic ordo decurionum ornamenta... decrevit. Forme pubbliche di riconoscimento del successo personale nell'Italia romana", in C. Berrendonner, M. Cébeillac-Gervasoni, and L. Lamoine (dirs.), Le quotidien municipal dans l'Occident romain, Clermont-Ferrand, 661-685.

Grey, C. 2011 Constructing Communities in the Late Roman Countryside, Cambridge.

Harmand, L. 1957 Le patronat sur les colectivités publiques, des origines au BasEmpire, Paris.

Harries, J. 1999 Law and Empire in Late Antiquity, Cambridge.

Harries, J. 2003 “Favor populi. Pagans, Christians and public entertainment in late antique Italy", in K. Lomas and T. Cornell (eds), 'Bread and Circuses'. Evergetism and municipal patronage in Roman Italy, London, 125-141

Horster, M. 1998 “Ehrungen spätantiker Statthalter”, in AnTard, 6, 37-59.

Horster, M. 2016 "Provincial governors and senatorial office-holders", in R. R. R. Smith and B. Ward-Perkins (dirs.), The Last Statues of Antiquity, Oxford, 239-248.

Hugoniot, C. 2002 "Les acclamations dans la vie municipal tardive et la critique augustinienne des violences lors des spectacles Africains", in H. Inglebert (dir.), Idéologies et valeurs civiques dans le Monde Romain, Nanterre, 179-187.

Iasiello, I. 2007 Samnium. Assetti e trasformazioni di una provincial dell'Italia tardoantica, Bari.

Jacques, F. 2018 Le privilege de liberté. Politique impériale et autonomie municipale dans les cités de l'Occident romain (161-244), Rome (or. ed. 1984). 
Jones, A. H. M. 1964 The Later Roman Empire. A Social, Economic, and Administrative Survey, 3 vols., Oxford.

Krause, J.-U. 1987 Spätantike patronatsformen im Westen des Römischen Reiches, Munich.

Lendon, J. 1997 Empire of Honour, Oxford.

Lenski, N. 2016 Constantine and the Cities: imperial authority and civic politics, Philadelphia.

Lepelley, C. 1979-1981 Les cités de l'Afrique romaine au Bas-Empire, 2 vols., Paris.

Lepelley, C. 1992 "Permanences de la cite classique et archaïsmes municipaux en Italie au Bas-Empire", in Institutions, société et vie politique dans l'Empire romain au IVe siècle ap. J.-C., Rome, 353-371.

Liebenam, W. 1967 Stadtverwaltung im römischen Kaiserreiche, Rome.

Liebeschuetz, W. 2001 The Decline and Fall of the Roman City, Oxford.

Liou, B. 1969 Praetores Etruriae XV populorum, Brussels.

Liu, J. 2009 Collegia Centonariorum: The Guilds of Textile Dealers in the Roman West, Leiden.

Liu, J. 2012 "Late antique fora and public honour in the western cities: case studies", in D. Brakke and D. Delyannis (eds), Shifting Cultural Frontiers in Late Antiquity, Farnham, 224-253.

Liverani, P. 2016 “The Sunset of 3D”, in T. M. Kristensen and L. Stirling (dirs.), The Afterlife of Greek and Roman Sculpture, Ann Arbor, 310-329.

Liverani, P. 2018. "Il ritratto dipinto in età tardoantica", in T. Greub and M. Roussel (dirs.), Figurationen des Porträts, Padeborn, 299-332.

Ma, J. 2013, Statues and Cities: honorific portraits and civic identity in the Hellenistic world, Oxford.

Machado, C. 2009, "Religion as antiquarianism: pagan dedications in late antique

Rome", in M. Kajava and J. Bodel (dirs.), Religious Dedications in the Greco-Roman World. Distribution, Typology, Use, Rome, 331-353.

Machado, 2010, "Public Monuments and Civic Life: the end of the statue habit in Italy", in P. Delogu and S. Gasparri (dirs.), Le trasformazioni del V secolo. L'Italia, $i$ Barbari e l'Occidente romano, Turnhout, 237-257.

Machado, C. 2016 "Italy", in R. R. R. Smith and B. Ward-Perkins (dirs.), The Last Statues of Antiquity, Oxford, 43-55. 
Machado, C. 2017 "Dedicated to Eternity? The reuse of statue bases in late antique Italy", in K. Bolle, C. Machado, and C. Witschel (eds) The Epigraphic Cultures of Late Antiquity, Stuttgart, 323-361.

Machado, C. with Lenaghan, J. 2016. "Rome", in R. R. R. Smith and B. WardPerkins (dirs.), The Last Statues of Antiquity, Oxford, 121-135.

Magalhães de Oliveira, J. C. 2012. 'Potestas populi': participation populaire et action collective dans les villes de l'Afrique romaine tardive: vers 300-430 apr. J.-C., Turnhout.

Mango, C. 1986 The Art of the Byzantine Empire, 312-1453, Toronto.

Marazzi, F. 2006 "Cadavera urbium, nuove capitali e Roma aeterna: l'identità urbana in Italia fra crisi, rinascita e propaganda (secoli III-V)", in J.-U. Krause and C. Witschel (eds) Die Stadt in der Spätantike. Niedergang oder Wandel?, Stuttgart, 3365.

Martin, F. 1996 "The importance of honorific statues. A case study", in Bulletin of the Institute of Classical Studies, 41, 53-50.

Mauss, M. 1990 The Gift: the form and reason for exchange in archaic societies, London (or. ed. 1923-1924).

Milano, I. and Pistarino, V. 2008 "Le iscrizioni sepolcrali con formule LDDD in Italia", in C. Berrendonner, M. Cébeillac-Gervasoni, and L. Lamoine (dirs.), Le quotidien municipal dans l'Occident romain, Clermont-Ferrand, 687-713.

Mollat, M. 1978 Les pauvres au Moyen âge: étude sociale, Paris.

Nicols, J. 1980 "Tabulae patronatus: A study of the agreement between Patron and Client-community", in $A N R W$, II.13, 535-561.

Parma, A. 2006 "Un nuovo decreto decurionale di Luceria del 327 d.C.", in M. Silvestrini, G.Volpe, and T. Spagnuolo Vigorita (dirs.), Studi in onore di Francesco Grelle, Bari, 201-214.

Patlagean, E. 1977 Pauvreté économique et pauvreté sociale à Byzance, 4e-7e siècles, Paris.

Pugliese Carratelli, G. (dir.) 1998 L'Italia meridionale in età tardoantica. Atti del trentottesimo convegno di studi sulla Magna Grecia, Naples.

Rawson, E. 1987 "Discrimina ordinum: The Lex Iulia Theatralis", in PBSR, 55, 83114.

Roueché, C. 1984 "Acclamations in the Later Roman Empire: New Evidence from Aphrodisias", in JRS, 74, 181-199. 
Roueché, C. 1998 "The functions of the governor in Late Antiquity: some observations", in AnTard, 6, 31-36.

Sabbatini Tumolesi, P. 1990 "Una nuova tabula patronatus da Paestum", in Miscellanea Greca e Romana 15, 235-256.

Salomies, O. 2015 "Making sense of a tabula patronatus from Amiternum of AD 325 (AE 1937, 119)", in Arctos, 49, 161-194.

Satlow, M. (ed) 2013 The Gift in Antiquity, Hoboken.

Savino, E. 2005 Campania tardoantica (284-604 d.C.), Bari.

Sear, F. 2006 Roman Theatres: an architectural study, Oxford.

Slootjes, D. 2006 The Governor and his Subjects in the Later Roman Empire, Leiden.

Smith, R. R. R. 1990 "Late Roman Philosopher Portraits from Aphrodisias”, in JRS, $80,127-155$.

Smith, R. R. R. 1999 "Late Antique Portraits in a Public Context: Honorific Statuary at Aphrodisias in Caria, AD 300-600”, in JRS, 89, 155-189.

Smith, R. R. R. 2016 "Statue practice in the late Roman empire: numbers, costumes, and style", in R. R. R. Smith and B. Ward-Perkins (dirs.), The Last Statues of Antiquity, Oxford, 1-27.

Solin, H. 1993 Le iscrizioni antiche di Trebula, Caiatia e Cubulteria, Caserta.

Solin, H. 2016 "Sulle trasformazioni amministrative di Casinum", in F. Mainardis (dir.), Voce concordi. Scritti per Claudio Zaccaria (Antichità Altoadriatiche, 85), Aquileia, 667-686.

Sotinel, C. 2005 Identité civique et christianisme. Aquilée du IIIe au VIe siècle, Rome.

Tantillo, I. 2017 'Statue, colore e ritratti nell'Occidente tardoromano. Su una perduta iscrizione di Aquino", in S. Antolini, S. Marengo, and G. Paci (dirs.), Colonie e municipi nell'era digitale, Tivoli, 615-634.

Tantillo, I. and Bigi, F. (eds) 2010 Leptis Magna. Una città e le sue iscrizioni in epoca tardoromana, Casino.

Torelli, M. 1995 "Towards the History of Etruria in the Imperial Period”, in Studies in the Romanization of Italy, Edmonton, 79-96 (or. ed. 1971).

Torelli, Marina 2002 Benevento Romana, Rome.

Veyne, P. 1976 Le pain et le cirque, Paris.

Wallace-Hadrill, A. (ed) 1989 Patronage in Ancient Society, London. 
Wallace-Hadrill, A. 1990 "Roman arches and Greek honours: the language of power at Rome", in Proceedings of the Cambridge Philological Society, 216, 143-181.

Ward-Perkins, B. 1984 From Classical Antiquity to the Middle Ages. Urban public building in Northern and Central Italy: AD 300-850, Oxford.

Ward-Perkins, B. 2016 "Statues at the end of antiquity: the evidence of the inscribed bases", in R. R. R. Smith and B. Ward-Perkins (dirs.), The Last statues of Antiquity, Oxford, 28-40.

Weisweiler, J. 2012 "From equality to asymmetry: honorific statues, imperial power, and senatorial identity in late-antique Rome", JRA, 25, 319-350.

Wistrand, E. 1981 "Popular politics in an Italian Municipality (CIL V 5049=CE 417)", Eranos, 79, 105-116.

Witschel, C. 2001 "Rom und die Städte Italiens in Spätantike und Frühmittelalter", Bonner Jahrbücher, 201, 113-162.

Witschel, C. 2006 "Der epigraphic habit in der Spätantike: Das Beispiel der Provinz Venetia et Histria", in J.-U. Krause and C. Witschel (eds) Die Stadt in der Spätantike. Niedergang oder Wandel?, Stuttgart, 359-411.

Witschel, C. 2007 "Statuen auf spätantiken Platzanlagen in Italien und Africa", in F. A. Bauer and C. Witschel (dirs.), Statuen in der Spätantike, Wiesbaden, 113-169. Yasin, A. M. 2009 Saints and Church Spaces in the Late Antique Mediterranean, Cambridge.

Zuddas, E. 2017 "La praetura Etruriae tardoantica”, in G. A. Cecconi, A. Raggi, and E. Salomone Gaggero (eds), Epigrafia e società dell'Etruria romana. Atti del Convegno di Firenze, 23-24 ottobre 2015, Rome, 217-235. 